\title{
SMALL LOCAL BANKS IN SOCIAL MEDIA: CONVERTING SOCIAL RESPONSIBILITY INTO CONSUMER ATTENTION AND ECONOMIC OUTCOMES
}

\author{
Łukasz KOZŁOWSKI(1) ${ }^{*}$, Iwa KUCHCIAK (1)2 \\ ${ }^{1}$ Department of Banking, Insurance, and Risk, Kozminski University, \\ Jagiellońska 57/59, 03-301 Warsaw, Poland \\ ${ }^{2}$ Institute of Finance, Faculty of Economics and Sociology, \\ University of Lodz, POW nr 3/5, 90-255 Lodz, Poland
}

Received 02 June 2020; accepted 24 February 2021

\begin{abstract}
This study investigates the thematic content of Facebook disclosures from small local banks (SLBs) in Poland, their impact on Facebook users' attention, and the economic repercussions for SLBs' growth and performance. Based on the specificity of SLBs and existing empirical evidence, it hypothesizes that disclosures on socially responsible issues increase customer attention and can be converted into economic outcomes. To verify the posed hypotheses, several data sources are employed, including a hand-collected dataset describing the specificity of Facebook activities from SLBs in Poland between 2010 and 2017, and a stepwise research strategy is implemented. First, models of SLBs' Facebook disclosures are distinguished. Second, the kinds of social media activities that ensure SLBs' popularity among Facebook users are determined. Third, the thematic content of SLBs Facebook disclosures is related to their growth or performance indicators. The collected evidence shows that SLBs, as expected, can garner attention if they concentrate their social media activities mainly on socially responsible or local issues. Moreover, socially responsible activities and economic outcomes are generally not opposed, but only a careful selection of specific social disclosures can effectively exploit social media to the economic advantage of SLBs.
\end{abstract}

Keywords: local banks, cooperative banks, social media, Facebook, corporate social responsibility, CSR, customer interest.

JEL Classification: M310, G21.

\section{Introduction}

Social media have become a natural part of daily life for billions of people. In 2020, their users numbered 4.1 billion, up 12\% from 2019. Among social media platforms, the most popular are Facebook and YouTube with respectively 2.7 billion and 2.0 billion users (We Are Social, 2020). Social media promote the creation and support of social interactions,

${ }^{\star}$ Corresponding author. E-mail: lkozlowski@kozminski.edu.pl

Copyright (c) 2021 The Author(s). Published by Vilnius Gediminas Technical University

This is an Open Access article distributed under the terms of the Creative Commons Attribution License (http://creativecommons. org/licenses/by/4.0/), which permits unrestricted use, distribution, and reproduction in any medium, provided the original author and source are credited. 
collaboration, and information exchange between users, and provide the largest, richest, and the most dynamic source of human behavior information, offering new opportunities to understand individuals, groups, and societies. Social media has also rapidly become a crucial communication tool not only for information generation and dissemination, but also for consumption during COVID-19 lockdown (Naeem, 2020; Wong et al., 2020). At the same time, the rapid diffusion of social media applications creates possibilities for companies to customize communication with customers, enhance collaborative initiatives, and collect evidence for strategic planning (Rimkunienè \& Zinkeviciute, 2014). Social media is also of interest to many researchers. Current empirical evidence related to the impact of social media on economic outcomes mainly concerns the strengthening of customer-company relationships and engagement (Mangold \& Faulds, 2009; Kaplan \& Haenlein, 2010; Bolton, 2011; Tsimonis \& Dimitriadis, 2014; Laroche et al., 2012; Lipsman et al., 2012; Durkin et al., 2014; Guesalaga, 2016; Gong, 2018), improving marketing efficiency (Edelman, 2010; Gallaugher \& Ransbotham, 2010; Pozza, 2014; Cawsey \& Rowley, 2016; Appel et al., 2020), stimulating brand awareness and loyalty (Silver \& Vegholm, 2009; Farshid et al., 2011; Laroche et al., 2013; Larsson \& Vitaoja, 2017), influencing purchase intentions (Adjei et al., 2010; Ponte et al., 2015; Chiang \& Tseng, 2017) and the impact of Covid-19 pandemic on consumer behavior (Naeem, 2020; Sheth, 2020). Although contributions on the social media phenomenon in the context of marketing and customer relationship management are widely recognized in the literature, studies related to the financial aspects of social media adoption are relatively scarce, and concern mostly non-financial companies and links between social media investments and firm value or performance (Plangger, 2012; Paniagua \& Sapena, 2014; Kim et al., 2015a, 2015b; Hsu \& Lawrence, 2016). Within that context, the literature strand related to the impact of social media on financial companies seems especially underdeveloped (Filip et al., 2017; Tang et al., 2016), and it does not take into account diversity of social media content and different models of corporate social media activity. This manuscript tries to fill this literature gap. Namely, it aims to distinguish different types of social media disclosures by small local banks in order to investigate these types' impact on customer attention, and - finally - on bank growth and performance.

Although global corporations are noted for successfully adopting social media, researchers confirm the effective utilization of social media in local communities, as well, as they increase the efficiency of interactions among community members and amalgamate information (Welch et al., 2005; Bonsón et al., 2012; Lev-On \& Steinfeld, 2015; Guillamón et al., 2016). This study looks at social media from a similar point of view, that is, it analyzes its use in a local context. To be more precise, the study investigates models of social media activity of small local banks (SLBs) in Poland and the consequences of their adoption on SLBs' growth and performance. The investigations concentrate on Facebook as it enables a wide and diversified range of interactions between its users and links companies with people of all ages. In contrast, Instagram or Twitter engage less diverse users and are aimed at less diversified information transfer (mostly photos or mostly text messages) which reduces marketing possibilities. In addition, Facebook is by far the most popular social media platform among Polish banks. In 2017, the number of cooperative banks which were Facebook-active 
at least to a minor extent was equal to 137 entities (around one-third of all the banks in the cooperative sector), while other social media channels are much less used by the analyzed banks (86 cooperative banks had published videos on YouTube, whereas only 15 were active on GoldenLine, that is, a Polish equivalent to LinkedIn, 4 on Instagram, 5 on LinkedIn, and just 3 on Twitter). In turn, while measuring the economic performance of banks, the study concentrates on the following indicators: asset/deposit/loan growth rate, net interest margin, profitability ratio, and the ratio of loan loss provisions to loans. The study defines two research goals. First, it determines the types of thematic content within social media activities that increase popularity among social media users. Then, it checks whether social media attention brings about economic outcomes, that is, stimulates bank growth or performance. To achieve the goals, four data sources are employed: a hand-collected dataset describing the specificity of Facebook activities of SLBs in Poland between 2010 and 2017, financial statements of those banks from the same period, the locations of bank branches, and data indicating the local economic environment for all counties in Poland. After combining the datasets, a stepwise research strategy is implemented. First, taking into account the previous empirical findings, the local character of analyzed banks, and their organizational form (cooperatives), models of Facebook disclosures are distinguished. In the second step, the study determines the kinds of social media activities (including a general Facebook disclosure model) that are popular among Facebook users. Then, in the third step of the study, the investigations aim to relate the thematic content of disclosures to bank growth or performance indicators to verify whether the initial attention gains resulting from Facebook disclosures have economic repercussions for SLBs. After estimating a series of regression models and constructing robustness checks, the collected evidence shows that SLBs, as expected, are able to draw attention if they concentrate their social media activities on socially responsible or local issues, but the conversion into bank growth or increased performance is less straightforward and more nuanced. Namely, it is not enough for a bank just to provide coverage on local events but to show a bank's own activity within the local community, especially in terms of charitable activities. In other words, socially responsible activities and economic outcomes are not contradictory, but only a prudent selection of social disclosures works to the economic advantage of SLBs.

The study contributes to the literature in three ways. First, it extends the scarce evidence on social media adoption by financial companies, including banks, and its economic consequences. Second, its clearly defines different types of social media disclosures from local firms and their levels of popularity among social media users, that is, it does not concentrate on the volume of social media activities but on the content within identified thematic categories. Third, it strictly differentiates between the initial attention gains resulting from Facebook activity and their final economic repercussions. The study has also managerial implications. It shows that a route from drawing attention of Facebook users to economic outcomes is not straightforward, and only some disclosures on socially responsible activities contribute to financial performance. However, the study provides evidence that socially responsible activities and economic effects do not contradict, and SLBs can successfully employ social media in their unique and traditional business strategies, which combine strictly commercial functions with support to their local communities. 
The remainder of this paper is structured in five parts. The first part provides an institutional background. The second part discusses the literature and existing empirical evidence. The third section outlines the data and methodology. The fourth section discusses the results and robustness checks, and the final section concludes the study.

\section{Literature review}

The purpose of this investigation is to extend the existing evidence on the relationship between a company's social media activities and economic outcomes. However, the study analyzes how this link can be established and refer to the special context of disclosures on Corporate Social Responsibility (CSR). The investigations are based on the concept illustrated in Figure 1. Thus, it is argued that social media activities differ in their nature and aim, but some of them can contribute to improved public image of a firm and increased attention of its customers, which - in turn - translate into economic outcomes. Thus, in order to properly reflect this mechanism, the study verifies the impact exerted by different types of social media activities on: (a) public image/customer attention (the direct channel), and (b) economic outcomes (the indirect channel). As a result of this approach, the study is based on complementary literature strands discussing each of those channels. The first strand concerns the direct channel, that is, the thematic content of a company's social media presence and its impact on public image/customer attention, while the second one focuses on the indirect impact of social media activities on firm performance. As the study analyzes the possibility to establish the indirect link through CSR, it additionally refers to the auxiliary literature on CSR and its impact on customer attention and firm performance without the particular reference to social media.

Within the first literature strand - which focuses on the impact of social media activities on customer attention - it is argued that social media strengthen long-term relationships with clients (Mangold \& Faulds, 2009; Kaplan \& Haenlein, 2010; Laroche et al., 2012; Lipsman et al., 2012; Durkin et al., 2014), improve the efficiency of marketing efforts (Edelman, 2010; Gallaugher \& Ransbotham, 2010; Pozza, 2014; Cawsey \& Rowley, 2016), increase con-

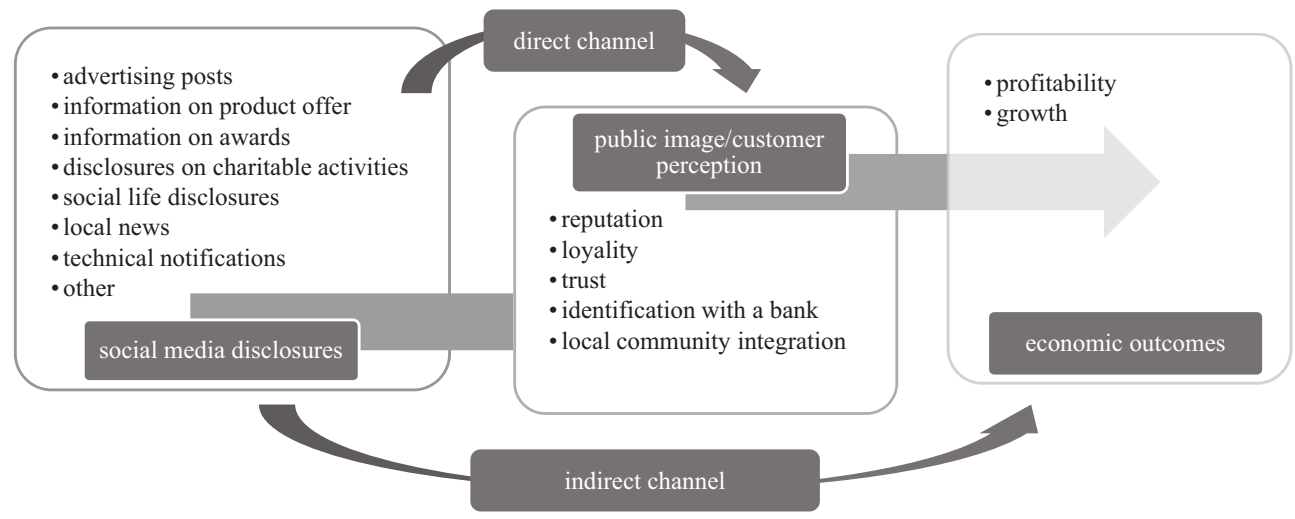

Figure 1. Relationship between social media disclosures and economic outcomes 
sumer engagement (Bolton, 2011; Tsimonis \& Dimitriadis, 2014), and stimulate brand awareness, loyalty, and trust (Silver \& Vegholm, 2009; Farshid et al., 2011; Laroche et al., 2013; Larsson \& Vitaoja, 2017). Nevertheless, it should be remembered that social media use does not unconditionally work to the advantage of a firm-customer relationship; that is, a success in social media activity is fundamentally dependent on the way in which selected types of social media are adopted. For example, in the context of small firm-bank relationships, Durkin et al. (2014) find that social media are most effective when used in a secondary capacity to personal face-to-face relationship building. In addition, Kaplan and Haenlein (2010) and Öberseder, Schlegelmilch, and Murphy (2013) claim that a company should carefully pursue a social media strategy, that is, choose a type of medium (as each social media channel usually attracts a certain group of people), be fair, respectful, and honest in communicating with customers, concentrate on engaging social media users in open and active conversations, and avoid overly professional content offerings. Thus, what matters is the content and specificity of social media activity rather than simply the decision to adopt them. In this context, Cvijikj and Michahelles (2011) argue that the characteristics of Facebook posts such as post type, category, and posting day influence users' interaction in terms of the number of comments and likes, as well as its duration. Ordenes, Grewal, Ludwig, Ruyter, Mahr, and Wetzels (2019) after two years of analyzing Facebook posts and Tweeter tweets demonstrate that the use of rhetorical style and cross-message composition enhance consumer message sharing. Further, Swani and Milne (2017) demonstrate that Facebook service messages generate more attention (measured by the number of comments) than goods messages, and Swani, Milne, and Brown (2013) suggest that the popularity of social media content is driven by the level of its functional and emotional appeals. In this respect, Ozdora-Aksaka and Atakan-Duman (2015) point out that Turkish banks construct their identity on social media accounts (Facebook and Twitter) by emphasizing their softer side (especially social responsibility). Thus, it can be argued that companies become aware that social responsibility is rewarded with more positive customer attitudes and higher levels of customer retention (van Doorn etal., 2017), and incorporate it within their social media strategies. A recent study by Uzunoğlu, Türkel, and Akyar (2017) finds that social media, particularly Twitter, necessitates companies to rigorously scrutinize message formulation and content generation efforts on issues related to social responsibility, as such messages have a higher impact on consumers' behavior than those in purely economic categories. Interestingly, they also argue that messages that combine issues from both economic and ethical areas have the highest impact on consumer attitude. These findings are supported by the CSR literature, which also indirectly justifies the need to demonstrate a company's social responsibility within social media activities. According to this literature strand, although people attach different weights to CSR disclosures, reflecting their internal life attitudes, they generally believe that companies must pay attention to issues beyond the narrow economic, technical and legal requirements, that is, to act in a socially responsible manner toward their customers at least to a specific degree (Lichtenstein et al., 2004; Ailawadi et al., 2014). Therefore, it is not surprising that the implementation and disclosure of socially responsible policies gains positive word of mouth, legitimizes operating in the local community, improves brand image and a firm's attractiveness, builds reputational advantage, and generates brand loyalty; that is, it generally leads to a company's strengthened 
relationships with customers (Drumwright, 1994; Creyer, 1997; Sen \& Bhattacharya, 2001; Fombrun, 2005; Sen et al., 2006; Marin \& Ruiz, 2007; Wigley, 2008; Du et al., 2010; Lii \& Lee, 2012; Lombart \& Louis, 2014; Pérez \& Del Bosque, 2015). Nevertheless, the effects seem to be dependent on the type of media used for disclosures, with Mercadé-Melé, Molinillo, Fernández-Morales, and Porcu (2018) arguing that the traditional medium model to disclose CSR is a better fit and has a greater overall effect than the social medium model. In the context of this study, it is worth stressing that the relationship between CSR disclosures and customers' perception has been also confirmed in the banking industry. For example, Mubarak, Ben Hamed, and Mubarak (2018), as well as Salehzadeh, Khazaei Pool, and Najafabadi (2018), find that corporate image is strengthened when banks adopt CSR, and Yusof, Manan, Karim, and Kassim (2015) note that customers pay special attention to a bank's clearly defined and implemented ethical values, philanthropic activity, and involvement in environmental issues. Using survey data, Polychronidoua, Ioannidoua, Kipourosa, Tsourgiannisb, and Simet (2014) show that banks use CSR to strengthen their image and attract more clients. In addition, Pérez and Del Bosque (2015) conclude that savings banks, as compared with commercial banks, require slightly different CSR disclosures to gain the most customer attention.

Taking into account the existing theoretical and empirical evidence, the local character of banks from the sample, and their organizational form (cooperatives), the first research hypothesis relates to the direct link between social media activities public image/customer perception:

H1: SLBs' CSR disclosures in social media increase the bank's popularity among social media users.

In line with Figure 1, social media disclosures may have a direct impact on a bank's public image and customer perception (reputation, loyalty, trust, identification with a bank, local community integration). In turn, the latter set of categories is linked with a bank's economic outcomes. As a result, social media activity is expected to be indirectly related to a firm's economic outcomes. Not only do theoretical deliberations support this claim, but also existing empirical evidence points at the financial effects of a company's social media activity and social media popularity. Plangger (2012) and Hsu and Lawrence (2016) report a positive relationship between social media investments and electronic word-of-mouth and firm value. Nevertheless, Paniagua and Sapena (2014) indicate that the positive effect of social media on firm value is exerted only if a critical mass of social media followers is attained. In a similar manner, several authors argue that substantial success in social media is required to translate it into economic performance. For example, Kim et al. (2015b) prove that an overall rating in social media is the most salient predictor of hotel performance. In the context of the banking industry, Tang et al. (2016) analyze the relationship between electronic word-ofmouth and firm profitability for a sample of 68 US banks and find that both star ratings and verbalized emotions (especially negative ones) are good predictors of bank performance. It is worth stressing that in the context of SLBs, Filip et al. (2017) find unappealing aspects of social media activity. Although they admit that social media presence can be a bank's valuable asset, they also highlight that SLBs must forego some of their market power to reach new customers or retain existing ones through new communication tools, especially when such 
tools are adopted relatively late and there is strong competition with other banks that are more advanced in social media or the Internet. Summing up, the existing empirical evidence indicates that the relationship between social media activity and firm performance could be conditional (critical mass of social media followers or sacrifice of market power may be required) or generally less achievable for late social media adopters and smaller companies.

Although researchers admit that attention in social media can be translated into a company's economic outcomes, they have not discussed what kinds of social media disclosures may lead to success, that is, the driving forces of this mechanism have not been thoroughly explained. The first discussed literature strand - which, as previously stated, focuses on the impact of social media activity on customer attention - proves that consumer interest depends on expressed emotions and inclusion of social matters in posts published by a company. Thus, taking into account this phenomenon and the specificity of banks in this study, it is worth referring once again to the auxiliary literature strand, which focuses on the relationship between socially responsible activities and firm performance. Most studies argue that socially responsible activities are positively associated not only with the prior but also future performance of a company; that is, social disclosures by companies have information content and the market usually values these positively (Anderson \& Frankle, 1980; Cochran \& Wood, 1984; Preston \& O’Bannon, 1997; Waddock \& Graves, 1997; Orlitzky et al., 2003; Porter \& Kramer, 2006). This link purportedly results from increased purchase intentions in the case of customers of socially responsible companies. It is even argued that CSR affect purchase intentions more strongly than price (Mohr \& Webb, 2005). In the special context of the banking industry, Wu and Shen (2013) argue that CSR positively associates with different performance measures, including return on assets, return on equity, net interest income, and non-interest income; however, it also increases the volume of non-performing loans. The latter finding directs to some exceptions from the common belief in the positive impact of CSR engagement on firm performance. For example, Lys, Naughton, and Wang (2015) suggest that the positive association between CSR expenditures and financial performance is more likely due to the signaling value of CSR expenditures than positive returns on those investments. To be more precise, they document that CSR expenditures are not a form of corporate charity nor do they improve future financial performance. Rather, firms undertake CSR expenditures in the current period when they anticipate stronger future financial performance. Hirigoyen and Poulain-Rehm (2015) go even further and show not only that greater social responsibility does not result in better financial performance, but also that financial performance negatively impacts corporate social responsibility. Finally, Lin, Law, and Sambasivan (2019) points at potential endogeneities in disclosed links between CSR and financial performance. Namely, their investigations of the Fortune Most Admired Companies provide evidence that better financial performance of firms lead to a better CSR engagement, but better CSR does not necessarily lead to superior CFP.

The contrasting conclusions from the abovementioned studies indicate that the relationship between socially responsible disclosures (including disclosures in social media) and firm performance is more nuanced than the common belief suggests. In addition, several authors show that this phenomenon is conditional upon factors related to the characteristics of a company or the environment in which it operates. For example, Servaes and Tamayo (2013) 
argue that corporate social responsibility and firm value are positively related for firms with high customer awareness, but for firms with low customer awareness, the relation is either negative or insignificant. Furthermore, Bolton (2013), using a sample of large U.S. banks, shows that the relationship between CSR and financial performance, measured with both operating performance and firm value, depends on the types of socially responsible activities a firm invests in, and that the types of CSR investments made by a bank matter more than their amount. In addition, Siueia, Wang, and Deladem (2019) analyze a sample of top-ranked banks in sub-Saharan Africa and found the level of development of a country to be an essential factor that links CSR disclosure and financial performance.

Although the first discussed literature strand consistently argues in favor of a positive relationship between CSR disclosures in social media and customer attention, the evidence from the remaining referenced studies is inconclusive and sometimes conditional. In the case of non-financial entities, the effects of the increased customer attention should be most clearly visible in the volume of a firm's sales. In a similar manner, in the case of the banking industry, one may expect that increased customer attention due to socially responsible activities within social media can be much more easily transformed into an extended customer base, the volume of loans or a company size than final performance indicators, including a bank's profitability, which bears the costs of CSR activities. Therefore, a general hypothesis $\mathrm{H} 2$ is formulated, but one cannot exclude its negative verification:

H2: SLBs' CSR disclosures in social media generates economic outcomes.

\section{Data description and methodology}

\subsection{Institutional background}

The Polish banking sector is composed of mostly large supra-local commercial banks and SLBs. The former group comprises 63 entities $^{1}$, and 549 cooperative banks make up the latter category $^{2}$. Although cooperative banks hold $9.6 \%$ of the banking sector's assets and $10.1 \%$ of deposits from non-financial entities, they provide payments to $20.2 \%$ of people employed in the sector (Polish Financial Supervision Authority [PFSA], 2019). This is a result of a widespread network of numerous branches, mostly located in less urbanized areas. Although cooperatives in the banking sector serve clients throughout the country, individual banks are strictly local entities. An average cooperative bank operates through 8 branches and is located in less than $1 \%$ of the counties, with the median distance between a bank's head office and a branch not exceeding $12 \mathrm{~km}$ for half of the banks. In comparison, for commercial banks, the same measure equals $252 \mathrm{~km}$.

It should be noted that cooperative banks generally follow unique business strategies, as they combine strictly commercial functions of banking product offers with support to their local communities in different cultural or social projects. Cooperative banks' strategies are aimed at local socio-economic challenges, as well as the promotion and financing

\footnotetext{
1 The group includes 35 banks domiciled in Poland and 28 branches of foreign financial institutions.

2 As per end of December 2018.
} 
of initiatives for sustainable local development (Giagnocavo et al., 2012), including caring for environmental resources and meeting the needs of purely local stakeholders (Carrasco, 2007). As fulfilling social missions is usually an important part of cooperative banks' business models, they are expected to implement CSR, i.e., corporate social responsibility (Cornelius et al., 2008; Ruostesaari \& Troberg, 2016), which means paying attention to issues beyond the narrow economic, technical, and legal requirements of a firm (Davis, 1973). The European Association of Cooperative Banks eagerly supports and promotes initiatives aimed at social responsibility from individual cooperative banks (European Association of Co-operative Banks, 2020), and SLBs' customers seem to appreciate their engagement in CSR, especially in promoting cultural and educational events and supporting the activities of local social and charitable organizations (Nowacka, 2016). Nevertheless, despite their involvement in socially responsible activities, cooperative banks are becoming increasingly similar to their purely commercial counterparts, that is, SLBs try to imitate the undertakings of commercial banks to survive in the market. For example, strong competition in the Polish banking sector forces cooperative banks to seek opportunities to reach new customers or retain existing ones through new communication tools, including social media. The first cooperative bank adopted Facebook as its communication channel in 2010, and the number of cooperative banks which were Facebook-active at least to a minor extent consistently grew to 137 entities in 2017 (around one-third of all the banks in the cooperative sector). Other social media channels are much less used by the analyzed banks. At the end of 2017, a group of 86 cooperative banks had published videos on YouTube, whereas only 15 were active on GoldenLine (a Polish equivalent to LinkedIn), 4 on Instagram, 5 on LinkedIn, and just 3 on Twitter. The way in which social media are used by SLBs still needs investigation; that is, whether SLBs try to exploit social media to the advantage of their traditional business model or employ them to achieve purely commercial goals is not yet understood.

\subsection{Data}

The study employs four data sources. First, it utilizes a unique, hand-collected dataset on the Facebook activity of 108 SLBs in Poland between 2010 and 2017. The data gathering process started in 2010. Twice a year (in January and July of each year), all posts published by banks in a preceding half-year were analyzed and assigned to thematic categories. In addition, the investigations included an analysis of Facebook-users' reaction to each post (likes, shares, and comments). It is worth stressing that the periodical investigation of social media activity allowed to collect unique data which are partly not available at the current moment (e.g., some Facebook profiles have been already removed). Finally, the sample does not cover banks without Facebook profiles at any moment between 2010 and 2017 or those with a negligible Facebook presence (i.e., entities with less than 30 published Facebook posts in the analyzed period). This approach is provoked by the goal and specificity of the study. Namely, the aim is not to study the impact of Facebook presence (regardless of its specificity) on bank performance, but the implications of variations in this presence on economic outcomes. Thus, the study compares and opposes different Facebook activity models to choose the one which is the most economically productive. In other words, it is not asked whether Facebook activ- 
ity generates outcomes, but investigated how to use Facebook to the advantage of a bank's performance.

The total number of posts published by the analyzed banks equals 27,548 . The median value of posts per bank is 177; a quarter of banks published less than 65 posts, whereas another quarter generated more than 370 posts. All posts were classified into eight categories, depending on the type of information they convey. The categories cover: (1) advertisements without reference to specific products, (2) product offers, (3) information about received thanks or awards, (4) information on a bank's charitable activities, (5) information related to a bank's social life (e.g., wishes given to an employee, announced competitions), (6) local news, (7) technical notifications (e.g., branch unavailability), and (8) posts that cannot be assigned to the other categories. The shares of posts published over the analyzed time horizon within these categories are calculated to obtain eight variables that define a bank's informational profile on Facebook: ADS, PROD, AWARD, CHARIT, SOCIAL, LOCAL, TECH, and OTHER, respectively. Additionally, Facebook users' responses to the banks' activities are reflected in the number of (1) likes, (2) shares (share button clicks), and (3) total comments per post between 2010 and 2017. Consequently, the following variables are obtained: LIKES, SHARES, and COMM, which are collectively called response variables. Panels A and B of Table 1 present detailed definitions of the variables related to SLBs' Facebook activity and users' responses.

Table 1. Variable definitions

\begin{tabular}{|l|l|}
\hline \multicolumn{2}{|c|}{ Panel A. Bank's informational profile on Facebook between 2010 and 2017} \\
\hline ADS & Share of advertising posts without product reference in all posts published by a bank \\
\hline PROD & Share of posts describing a bank's product offer in all posts published by a bank \\
\hline AWARD & Share of posts about received thanks or awards in all posts published by a bank \\
\hline CHARIT & Share of posts related to local charitable activities in all posts published by a bank \\
\hline SOCIAL & Share of posts related to a bank's social life in all posts published by a bank \\
\hline LOCAL & Share of posts expressing local news in all posts published by a bank \\
\hline TECH & Share of technical notifications in all posts published by a bank \\
\hline OTHER & $\begin{array}{l}\text { Share of all other posts (not included in the previous categories) in all posts } \\
\text { published by a bank }\end{array}$ \\
\hline \multicolumn{2}{|l|}{ Panel B. Facebook users' response between 2010 and 2017 } \\
\hline LIKES & Ratio of the number of likes by Facebook users to the number of a bank's posts \\
\hline SHARES & Ratio of the number of shares by Facebook users to the number of a bank's posts \\
\hline COMM & Ratio of the number of comments by Facebook users to the number of a bank's posts \\
\hline \multicolumn{2}{|c|}{ Panel C. Bank's financial characteristics (average values over the period 2010-2017) } \\
\hline SIZE & Natural logarithm of total assets in constant prices \\
\hline EQUITY & Ratio of equity to total assets \\
\hline LOANS & Ratio of loans to total assets \\
\hline PROFIT & Operating return on equity \\
\hline NIM & Ratio of net interest income to assets \\
\hline
\end{tabular}




\begin{tabular}{|l|l|}
\hline \multicolumn{2}{|c|}{ Panel C. Bank's financial characteristics (average values over the period 2010-2017) } \\
\hline COSTS & Ratio of overheads to operating income \\
\hline R.LOSS & Ratio of net loan loss provisions and average loans \\
\hline DEPO $\Delta$ & Yearly growth rate of deposits in constant prices \\
\hline LOAN $\Delta$ & Yearly growth rate of loans in constant prices \\
\hline ASSET $\Delta$ & Yearly growth rate of assets in constant prices \\
\hline \multicolumn{2}{|c|}{ Panel D. Local environment (average values over the period 2010-2017) } \\
\hline UNEMPL & $\begin{array}{l}\text { Unemployment rate in counties in which a bank operates in relation to the average } \\
\text { for the whole country }\end{array}$ \\
\hline POPUL & Population density in thousands of inhabitants $/ \mathrm{km}^{2}$ \\
\hline
\end{tabular}

Note: ${ }^{*}$ Values were averaged over counties in which a bank operated, with the number of a bank's outlets in individual counties used as weights.

Facebook users' responses to bank activities can be driven by various factors, some of them unrelated to a bank's Facebook activity profile. First, attractiveness of a bank's Facebook profile depends on the bank's investments into it, which - in turn - reflects the bank's perception of its usefulness. This phenomenon is reflected in previous empirical investigations that analyze social media investments and controlled for many firm-level factors, including at least a firm's size and age (Thong \& Yap, 1995; Wamba \& Carter, 2014; Siamagka et al., 2015; Cao et al., 2018), or directly pointed at the influence of a firm's financial characteristics (Dahnil et al., 2014; Jackowicz et al. 2020) or shortage of qualified personnel (Michaelidou et al., 2011). In a similar manner, a non-negligible effect on a bank's social media investments and attractiveness of a bank's social media profile is exerted by the local environment in which the bank operates. The environment defines the demand for a bank's social media presence. For example, the demand is likely to be higher in regions with a high percentage of college enrollees or elevated income per person (Courchane et al., 2002), determined by customer age (Durkin et al., 2015), or just increased in firms' typical market strongholds (Jackowicz et al., 2020). Thus, to adequately measure the impact of a bank's informational profile on Facebook users' responses and control for all potential factors, the dataset is enriched with information from three additional sources. The first source includes SLBs' financial statements for the analyzed time period. The second source consists of the information from Polish Central Statistical Office on the local economic environment in all 380 counties in Poland. The third dataset includes addresses of all bank branches in Poland that allows to determine the county in which each SLB's branches are located. Those additional datasets allow to construct two sets of variables, which are then employed as regressors (in the models explaining Facebook users' responses to SLBs' social media activities) or as dependent variables (in models explaining SLBs' growth and performance). First, the variables describe each bank's financial characteristics in the analyzed period ${ }^{3}$ by measuring a bank's size (SIZE; calculated as the natural logarithm of total assets in constant prices), solvency (EQUITY;

\footnotetext{
${ }_{3}$ As the study covers the period 2010-2017, average yearly observations for each bank are calculated.
} 
equity to assets ratio), asset structure (LOANS; loans to assets ratio), profitability (PROFIT; operating return on equity), interest margin (NIM; net interest income to assets ratio), cost management (COSTS; overhead to operating income ratio), loan portfolio quality (R.LOSS; approximated by the ratio of yearly net loan loss provisions and average loans), deposit growth rate $(D E P O \Delta)$, loan growth rate $(L O A N \Delta)$, and asset growth rate (ASSET $\Delta)$. Second, while employing the last two referenced sources, a bank's local environment is described with the population density (POPUL), and unemployment rate (UNEMPL). It should be noted that some SLBs have branches in more than one county. Therefore, to generate values that describe each bank's local environment, original county-level statistics were averaged over counties in which a bank operated, and the numbers of a bank's outlets in individual counties were used as weights. Panels $\mathrm{C}$ and $\mathrm{D}$ of Table 1 summarize definitions of the control variables, and Table 2 presents the relevant descriptive statistics of all variables in the study. The statistics show that an average bank in the sample concentrates its social media activities on advertisements and promotional posts related to product offers (44.2\% of all posts in total), whereas posts related to local and social issues (categories CHARITY, SOCIAL, and LOCAL) account for $30.4 \%$ all published posts. Nevertheless, individual banks potentially differ from this unrealistic average bank, as the post share in each of those categories has a substantial variation. This suggests that there are banks that concentrate their social media activity within a limited number of categories.

Table 2. Descriptive statistics

\begin{tabular}{|l|c|c|c|c|c|c|c|c|}
\hline Variable & Banks & Mean & Std. Dev. & Min & $1^{\text {st }}$ Quartile & $2^{\text {nd }}$ Quartile & $3^{\text {rd }}$ Quartile & Max \\
\hline ADS & 108 & 0.122 & 0.089 & 0.000 & 0.059 & 0.102 & 0.176 & 0.446 \\
\hline PROD & 108 & 0.320 & 0.147 & 0.045 & 0.211 & 0.305 & 0.404 & 0.758 \\
\hline AWARD & 108 & 0.038 & 0.051 & 0.000 & 0.006 & 0.020 & 0.053 & 0.287 \\
\hline CHARIT & 108 & 0.052 & 0.058 & 0.000 & 0.009 & 0.033 & 0.080 & 0.348 \\
\hline SOCIAL & 108 & 0.159 & 0.089 & 0.018 & 0.090 & 0.135 & 0.219 & 0.438 \\
\hline LOCAL & 108 & 0.093 & 0.083 & 0.000 & 0.029 & 0.073 & 0.132 & 0.412 \\
\hline TECH & 108 & 0.026 & 0.037 & 0.000 & 0.003 & 0.015 & 0.035 & 0.225 \\
\hline OTHER & 108 & 0.190 & 0.107 & 0.000 & 0.116 & 0.174 & 0.243 & 0.527 \\
\hline LIKES & 108 & 5.185 & 4.460 & 0.146 & 2.457 & 4.024 & 6.369 & 28.136 \\
\hline SHARES & 108 & 0.942 & 1.074 & 0.000 & 0.257 & 0.572 & 1.233 & 5.409 \\
\hline COMM & 108 & 0.286 & 0.610 & 0.000 & 0.054 & 0.123 & 0.265 & 5.667 \\
\hline SIZE & 108 & 18.935 & 0.791 & 17.525 & 18.330 & 18.874 & 19.399 & 21.444 \\
\hline EQUITY & 108 & 0.096 & 0.026 & 0.048 & 0.079 & 0.091 & 0.111 & 0.177 \\
\hline LOANS & 108 & 0.755 & 0.121 & 0.409 & 0.663 & 0.793 & 0.844 & 0.966 \\
\hline PROFIT & 108 & 0.084 & 0.038 & -0.025 & 0.062 & 0.083 & 0.109 & 0.178 \\
\hline NIM & 108 & 0.032 & 0.006 & 0.017 & 0.028 & 0.032 & 0.035 & 0.054 \\
\hline COSTS & 108 & 0.678 & 0.090 & 0.367 & 0.630 & 0.688 & 0.730 & 0.868 \\
\hline R.LOSS & 108 & 0.006 & 0.006 & -0.003 & 0.002 & 0.005 & 0.008 & 0.036 \\
\hline DEPO $\Delta$ & 108 & 0.104 & 0.049 & -0.052 & 0.070 & 0.106 & 0.139 & 0.227 \\
\hline LOAN $\Delta$ & 108 & 0.087 & 0.064 & -0.040 & 0.044 & 0.084 & 0.129 & 0.364 \\
\hline
\end{tabular}


End of Table 2

\begin{tabular}{|l|c|c|c|c|c|c|c|c|}
\hline \multicolumn{1}{|c|}{ Variable } & Banks & Mean & Std. Dev. & Min & $1^{\text {st }}$ Quartile & $2^{\text {nd }}$ Quartile & $3^{\text {rd }}$ Quartile & Max \\
\hline ASSET $\Delta$ & 108 & 0.097 & 0.048 & -0.042 & 0.065 & 0.098 & 0.130 & 0.228 \\
\hline UNEMPL & 108 & 1.179 & 0.507 & 0.353 & 0.817 & 1.094 & 1.432 & 2.644 \\
\hline POPUL & 108 & 0.289 & 0.328 & 0.036 & 0.097 & 0.156 & 0.374 & 2.354 \\
\hline
\end{tabular}

\subsection{Methodology}

To verify the hypotheses, a stepwise procedure is applied. First, with the use of k-medoid clustering, each bank is assigned to a model of Facebook activity, depending on the information structure conveyed in a bank's posts. The objective of this approach is to group banks with similar informational profiles into the same cluster (Kaufman \& Rousseeuw, 1990). The applied k-medoid algorithm uses the Manhattan distance - the sum of the horizontal and vertical distance between a pair of points - to identify clusters. The clusters are distinguished in such a manner that they ensure minimization of the differences between informational profiles (described by the variables ADS, PRODUCT, AWARD, CHARIT, SOCIAL, LOCAL, $T E C H$, and OTHER) of banks within a cluster, and maximization of differences between informational profiles of banks from different clusters.

In the second step of the investigations, hypothesis $\mathrm{H} 1$ is approached through the analysis of the relationship between the thematic content of SLBs' Facebook activity and Facebook users' responses. Thus, regression models are estimated through the ordinary least squares (OLS) method with robust standard errors. These models regress Facebook users' responses to a bank's posts against a set of explanatory variables suggested by the literature. These regressors describe a bank's financial characteristics and its local environment, as well as the thematic content of a bank's Facebook posts. A regressor that reflects the specificity of a bank's Facebook activity is either a dummy that identifies the Facebook activity model (from the first step of the analysis) or a variable that describes the share of specific types of posts out of all posts published by a bank (the variables ADS, PROD, AWARD, CHARIT, SOCIAL, LO$C A L, T E C H$, and $O T H E R$ ). The general construction of the models is illustrated by Eq. (1):

$$
R E S P_{i}=\mathrm{f}\left(F I N_{i} ; E N V_{i} ; F C_{i}\right),
$$

where $R E S P_{i}$ is a dependent variable representing Facebook users' responses to the content of the $i$-th bank's Facebook activity. To scrutinize the responses, within various estimations, the study employs the LIKES, SHARES, or COMM dependent variables, and the set of regressors includes a bank's financial characteristics (denoted collectively as $F I N_{i}$; the set includes variables SIZE, NIM, LOANS, EQUITY, PROFIT, and COSTS), its local environment $\left(E N V_{i}\right.$, including variables UNEMPL and POPUL), and a set of variables $\left(F C_{i}\right)$ reflecting the Facebook activity content.

From the perspective of an SLB, a suitable model of Facebook activity may stimulate the attention of Facebook users (hypothesis H1). Nevertheless, it does not automatically translate into economic outcomes, that is, the acquisition of customers, bank growth, and increased performance. Therefore, within the third step, the study verifies hypothesis H2. Thus, with the use of the OLS estimator with robust standard errors, different measures of an economic 
outcome are regressed against a set of explanatory variables. Eq. (2) presents the general construction of the models:

$$
\operatorname{ECON}_{i}=\mathrm{f}\left(F I N_{i} ; E N V_{i} ; F C_{i}\right),
$$

where $E C O N_{i}$ is a variable reflecting the $i$-th bank's growth (DEPO $\triangle, L O A N \triangle$, ASSETA) or its performance (NIM, R.LOSS, PROFIT). The set of variables FIN $_{i}$ controls for the $i$-th bank's specificity (variables SIZE, LOANS, EQUITY, and COSTS in all regressions, and additionally PROFIT and NIM in DEPO $\triangle$, LOANA, ASSET $\triangle$ models), and ENV $V_{i}$ describes its local environment (UNEMPL and POPUL). Finally, in various specifications, one variable from the $F C_{i}$ set is employed that reflects the thematic content of the i-th bank's Facebook activity.

\section{Results}

\subsection{Facebook activity models}

The analysis begins with a k-medoid clustering, which allows to identify the unique Facebook activity models of SLBs. The results of the clustering are presented in Table 3. Two clusters of banks are distinguished. The first includes 64 banks that devote their Facebook activities mainly to describing product offers: the medoid - a group representative - conveys product offers in $40.3 \%$ of its posts. Taking into account that an additional $8.9 \%$ of posts are advertisements that do not reference the bank's products, almost $50 \%$ of posts of this cluster's medoid have an economic connotation. Additionally, banks within this cluster inform their Facebook followers about charitable, social, or local issues to a minor extent. Taking these specificities into account, banks from this cluster are called Sales-Oriented. The second cluster is constituted of 44 SLBs. The medoid of this group conveys information about charitable activities in $9.4 \%$ of posts, $21.5 \%$ of posts are devoted to the bank's social issues, and $13.4 \%$ convey local news. Thus, $44.3 \%$ of posts can be treated as a representation of socially responsible disclosures, as compared to only $21.4 \%$ of such posts published by the medoid of the first

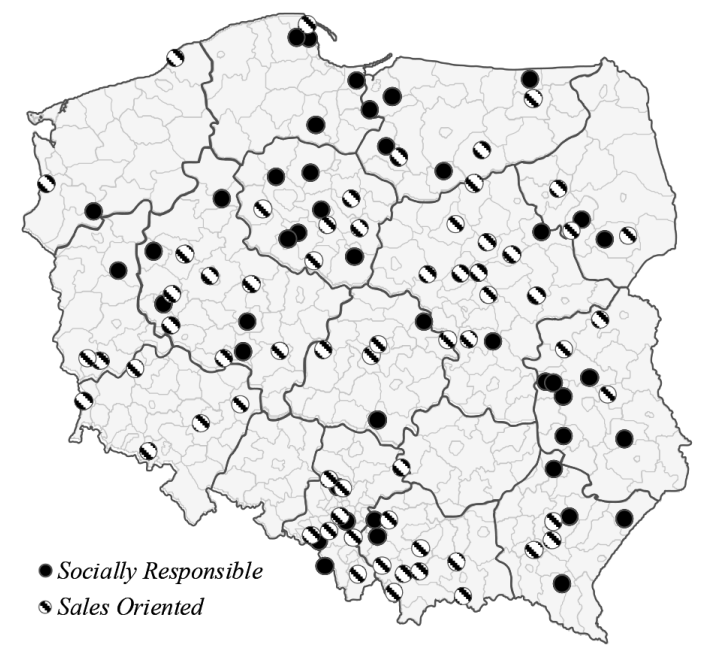

Figure 2. Geographical distribution of head offices of SLBs following the two represented Facebook activity models (source: author's own presentation) 
cluster. The dominance of social and local issues in the posts of SLBs from the second group prompts to call these banks Socially Responsible. Figure 2 shows the geographical distribution of SLBs following the two Facebook activity models. The banks are spread across the country, and there is no evident regularity in the location of banks from the same cluster. Thus, a conclusion can be formulated that regional factors do not significantly impact the SLBs' choice of Facebook activity models.

Table 3. SLBs' Facebook activity models (k-medoid clustering)

\begin{tabular}{|l|l|c|c|}
\hline \multirow{4}{*}{ Clustering variable } & $\begin{array}{c}\text { Cluster 1 } \\
\text { (Sales-Oriented })\end{array}$ & $\begin{array}{c}\text { Cluster 2 } \\
\text { (Socially Responsible) }\end{array}$ \\
\hline \multirow{4}{*}{ Medoids } & ADS & $8.9 \%$ & $7.4 \%$ \\
\cline { 2 - 4 } & PROD & $40.3 \%$ & $24.2 \%$ \\
\cline { 2 - 4 } & AWARD & $0.8 \%$ & $3.4 \%$ \\
\cline { 2 - 4 } & CHARIT & $1.2 \%$ & $9.4 \%$ \\
\cline { 2 - 4 } & SOCIAL & $13.3 \%$ & $21.5 \%$ \\
\cline { 2 - 4 } & LOCAL & $6.9 \%$ & $13.4 \%$ \\
\cline { 2 - 4 } & TECH & $1.2 \%$ & $0.7 \%$ \\
\cline { 2 - 4 } & OTHER & $27.4 \%$ & $20.1 \%$ \\
\hline \multirow{2}{*}{$\begin{array}{l}\text { Number of banks in } \\
\text { the cluster }\end{array}$} & & 64 & 44 \\
\hline
\end{tabular}

\subsection{Response to the Facebook disclosures}

Table 4 presents the results of the multivariate analysis in which regress proxies of Facebook users' attention are regressed against a set of control variables and a binary variable identifying banks with socially responsible activities in social media (distinguished in the first step of the analysis through the k-medoid clustering). It is worth stressing that the control variables are rarely statistically significant (at levels between 5 and 10\%), which suggests that a bank's financial standing and its location play minor roles in shaping Facebook users' interest in the bank's Facebook profile. These outcomes strongly contrast with estimation results for the dummy that identifies banks that disclose socially responsible information in social media. The Socially Responsible dummy is strongly statistically significant in two cases at levels below $1 \%$ and in one case at the $5 \%$ level. The estimation results are also economically significant. If a bank discloses information related to socially responsible issues, it may expect to record 3.3 more likes per post, or $63 \%$ more than the average in the sample. Disclosures on socially responsible issues also generate ca. $61 \%$ more shares and $120 \%$ more comments by Facebook users. To provide more details on the relationship between the thematic content of a bank's Facebook posts and consumer responses, the response variables (LIKES, SHARES, and $C O M M$ ) are additionally regressed against the same controls and each of the variables that describe the share of specific posts out of all posts published by a bank (ADS, PROD, AWARD, CHARIT, SOCIAL, LOCAL, TECH, and OTHER). Table 5 shows the respective estimation outcomes for the variables that describe the thematic content of posts; however, the coefficients for the control variables remain unreported for brevity. A few regularities 
can be observed within the estimation outcomes. First, information about charitable activities receives the highest interest from Facebook users. Coefficients for the CHARIT variable are statistically significant for all three specifications, and they show that an increase in the share of posts related to charitable activities by 10 percentage points is expected to increase the volume of received likes, shares, and comments by $66 \%, 55 \%$, and $36 \%$ of the respective averages within the sample. Second, the remaining categories of posts related to social or local issues (SOCIAL and LOCAL) do not exert such a pronounced impact on Facebook users' interest; that is, notifications on social events generate more comments only, and local news leads to more likes. Third, posts related to a bank's product offer play an opposite role in shaping Facebook users' responses. They are not liked, shared, or commented upon, and the respective coefficients are both statistically and economically significant; that is, an increase in the share of posts that describe a bank's product offer by 10 percentage points reduces received likes, shares, and comments by $14 \%, 12 \%$, and $20 \%$ of the respective averages within the sample. Fourth, posts about awards received by a bank increase Facebook users' likes and shares, whereas notifications about technical issues work in the opposite direction in the case of received likes. Both outcomes are not surprising. Although received awards generally have a positive effect on a bank's brand image and can potentially stimulate Facebook users' interest, one cannot expect technical notifications (which include information about branch unavailability and other temporary problems) to be liked by customers. When the outcomes from Tables 4 and 5 are taken together, all disclosures related to the social responsibility of a bank (the Socially Responsible variable) play a clearly positive role in shaping Facebook users' interest, but not all exert the same impact on each of the response variables.

Table 4. Responses to SLBs' socially responsible Facebook disclosures (source: author's own calculations)

\begin{tabular}{|l|c|c|c|}
\hline \multirow{2}{*}{ Dependent variable: } & $(1)$ & $(2)$ & $(3)$ \\
\hline \multirow{2}{*}{ SIZE } & LIKES & SHARES & COMM \\
\cline { 2 - 4 } & 0.600 & 0.121 & 0.0424 \\
\hline \multirow{2}{*}{ NIM } & $(0.697)$ & $(0.185)$ & $(0.0684)$ \\
\cline { 2 - 4 } & $282.8^{* *}$ & -0.581 & 20.96 \\
\hline \multirow{2}{*}{ LOANS } & $(142.1)$ & $(36.93)$ & $(14.23)$ \\
\hline \multirow{2}{*}{ EQUITY } & -0.699 & -1.019 & $-0.689^{*}$ \\
\hline \multirow{2}{*}{ PROFIT } & $(2.448)$ & $(0.730)$ & $(0.393)$ \\
\cline { 2 - 4 } & $-79.66^{* *}$ & 3.136 & -3.562 \\
\hline \multirow{2}{*}{ COSTS } & $(36.92)$ & $(11.11)$ & $(4.203)$ \\
\cline { 2 - 4 } & $-19.40^{*}$ & 2.439 & -0.667 \\
\cline { 2 - 4 } & $(9.888)$ & $(3.106)$ & $(1.070)$ \\
\cline { 2 - 4 } & 0.266 & 1.065 & -0.722 \\
\cline { 2 - 4 } & $(4.588)$ & $(1.253)$ & $(0.586)$ \\
\hline \multirow{2}{*}{ POPUL } & 0.521 & 0.0244 & 0.0680 \\
\cline { 2 - 4 } & $(0.593)$ & $(0.212)$ & -0.169 \\
\hline
\end{tabular}


End of Table 4

\begin{tabular}{|l|c|c|c|}
\hline \multirow{2}{*}{ Socially Responsible } & $(1)$ & $(2)$ & $(3)$ \\
\cline { 2 - 4 } & $3.296^{* * *}$ & $0.576^{* * *}$ & $0.344^{* *}$ \\
\hline \multirow{2}{*}{ Constant } & $(0.824)$ & $(0.197)$ & $(0.138)$ \\
\cline { 2 - 4 } & -0.0904 & -2.863 & 0.302 \\
\hline Banks & $(17.08)$ & $(4.518)$ & $1.824)$ \\
\hline R-squared & 108 & 108 & 0.132 \\
\hline
\end{tabular}

Note: Robust standard errors are presented in parentheses; ${ }^{*},{ }^{* *}$, and ${ }^{* * *}$ refer to statistical significance at the $10 \%, 5 \%$, and $1 \%$ levels, respectively.

Table 5. Responses to the content of SLBs' Facebook posts (source: author's own calculations)

\begin{tabular}{|c|c|c|c|c|c|c|c|c|}
\hline & (1) & (2) & (3) & (4) & (5) & (6) & (7) & (8) \\
\hline $\begin{array}{l}\text { Dependent } \\
\text { variable: }\end{array}$ & LIKES & LIKES & LIKES & LIKES & LIKES & LIKES & LIKES & LIKES \\
\hline $\begin{array}{l}\text { Regressor } \\
\text { describing posts: }\end{array}$ & ADS & PROD & AWARD & CHARIT & SOCIAL & LOCAL & TECH & OTHER \\
\hline \multirow[t]{3}{*}{$\begin{array}{l}\text { Coefficient for } \\
\text { the regressor: }\end{array}$} & -2.342 & $-7.194^{\star *}$ & $17.91^{* *}$ & $34.00^{\star * *}$ & 1.388 & $16.33^{\star \star}$ & $-19.54^{* * *}$ & -4.587 \\
\hline & $(5.856)$ & (3.449) & (7.951) & $(11.27)$ & $(5.155)$ & $(6.685)$ & $(6.887)$ & $(3.815)$ \\
\hline & (9) & (10) & (11) & (12) & (13) & (14) & (15) & (16) \\
\hline $\begin{array}{l}\text { Dependent } \\
\text { variable: }\end{array}$ & SHARES & SHARES & SHARES & SHARES & SHARES & SHARES & SHARES & SHARES \\
\hline $\begin{array}{l}\text { Regressor } \\
\text { describing posts: }\end{array}$ & ADS & PROD & AWARD & CHARIT & SOCIAL & LOCAL & $\mathrm{TECH}$ & OTHER \\
\hline \multirow[t]{3}{*}{$\begin{array}{l}\text { Coefficient for } \\
\text { the regressor: }\end{array}$} & 0.0625 & $-1.118^{*}$ & $5.278^{\star *}$ & $5.173^{\star *}$ & 1.047 & 0.413 & 1.601 & $-1.594^{\star *}$ \\
\hline & $(1.232)$ & $(0.606)$ & $(2.437)$ & $(2.170)$ & $(1.103)$ & \begin{tabular}{|l|}
$(1.258)$ \\
\end{tabular} & $(2.491)$ & $(0.793)$ \\
\hline & $(17)$ & (18) & (19) & $(20)$ & $(21)$ & (22) & (23) & (24) \\
\hline $\begin{array}{l}\text { Dependent } \\
\text { variable: }\end{array}$ & COMM & $\mathrm{COMM}$ & COMM & $\mathrm{COMM}$ & COMM & COMM & COMM & COMM \\
\hline $\begin{array}{l}\text { Regressor } \\
\text { describing posts: }\end{array}$ & ADS & PROD & AWARD & CHARIT & SOCIAL & LOCAL & $\mathrm{TECH}$ & OTHER \\
\hline \multirow[t]{2}{*}{$\begin{array}{l}\text { Coefficient for } \\
\text { the regressor: }\end{array}$} & -0.429 & $-0.582^{\star * *}$ & -1.253 & $1.026^{*}$ & $2.073^{\star \star}$ & 1.837 & -1.161 & $-0.849^{* *}$ \\
\hline & $(0.533)$ & $(0.215)$ & $(1.537)$ & $(0.570)$ & $(0.831)$ & (1.336) & $(1.013)$ & $(0.379)$ \\
\hline Banks & 108 & 108 & 108 & 108 & 108 & 108 & 108 & 108 \\
\hline R-squared & 0.066 & 0.079 & 0.071 & 0.070 & 0.146 & 0.107 & 0.067 & 0.083 \\
\hline
\end{tabular}

Note: For brevity, coefficients for the control variables (SIZE, NIM, LOANS, EQUITY, PROFIT, COSTS, UNEMPL, and POPUL), constant term, and R-squared are not reported. Robust standard errors are presented in parentheses; ${ }^{\star},{ }^{* *}$, and ${ }^{* * *}$ refer to statistical significance at the $10 \%, 5 \%$, and $1 \%$ levels, respectively. 


\subsection{Facebook activity models and their relationship with bank growth and performance}

Tables 6 and 7 address hypothesis H2, which concerns the relationship between the specificity of SLBs' Facebook activity and their growth or performance. Unsurprisingly, in contrast to outcomes reported in Table 4, some bank-level controls and regressors that describe a bank's local environment are statistically significantly related to the dependent variables. For example, well-capitalized (EQUITY) and highly profitable (PROFIT) banks do not seem to struggle for new customers and report relatively slower growth rates in terms of deposits, loans, and total assets. In addition, it can be observed that SLBs' grow faster in less densely populated areas (POPUL), which makes sense if one takes into account that such areas are the usual SLB strongholds. However, SLBs are able to generate higher net interest margins (NIM) and, thus, higher profits (PROFIT) in more urbanized locations, but experience higher loan loss provisions (R.LOSS) in those areas. The latter phenomenon can be because, in more densely populated areas, SLBs are not able to fully exert their relationship lending model.

In the case of the binary variable identifying banks with socially responsible disclosures on their Facebook profiles, outcomes from Table 6 are also in sharp contrast with the results shown in Table 4. Although regressions from Table 4 consistently prove that socially responsible banks win the attention of Facebook users, there is no evidence that such attention automatically converts into new deposits or an increase in the deposit volume of existing customers (DEPOA). Similarly, all the coefficients for the Socially Responsible binary variable are statistically insignificant in the remaining regressions explaining bank growth or performance. To obtain a full picture of the analyzed phenomenon, the results from Table 7 are scrutinized. This table presents estimation outcomes for models in which selected measures of bank growth or performance are regressed against control variables (for brevity, they remain unreported) and individual variables that describe the share of specific types of posts out of all posts published by a bank on its Facebook profile. A few types of Facebook activities seem to be significantly related to the thematic content of a bank's Facebook posts. First, banks with the highest amount of charitable activity disclosures draw more deponents $(D E P O \triangle)$ and borrowers (LOANA), generally grow the fastest (ASSET $\triangle)$, report the highest net interest margins (NIM), and have the most creditworthy borrowers (R.LOSS). These estimation outcomes are statistically significant and relevant in economic terms. For example, an increase in the share of disclosures on charitable activities by 7.1 percentage points (the sample's interquartile range) corresponds with an increase in the deposit growth rate by 1.5 percentage points, which is equivalent to $22 \%$ of this variable's interquartile range in the sample. In the case of the remaining variables that describe the thematic content of SLBs' Facebook posts, significantly fewer regularities can be observed. First, banks with more disclosed social events generate higher interest margins (NIM) and higher profitability (PROFIT). Those outcomes are in accordance with the results for the CHARIT variable, as they also show that a bank's disclosures about social responsibility pay off. Second, SLBs that post more local news generate lower deposit, loan, and asset growth rates; that is, they generally attract relatively fewer customers. In combination with the outcomes for the CHARIT and SOCIAL variables, the results suggest that it is not enough for a bank to provide coverage on local events but to prove its own activity within the local community. Third, the results for 
the AWARD regressor show that posted information about received awards and thanks correspond with higher net interest margins (NIM) and better loan loss management (R.LOSS). In summary, the results from Tables 6 and 7 taken together suggest that it is not easy for a bank to benefit from socially responsible disclosures on Facebook; that is, only selected types of disclosures correspond with increased growth or performance, and social responsibility in more general terms (the Socially Responsible dummy) may not pay off despite the significantly increased attention of Facebook users. Nevertheless, the results show that CSR disclosures and economic outcomes are generally not opposed, especially for SLBs. In fact, in the case of these entities, a careful selection of specific CSR disclosures is the only effective way to exploit social media to achieve the economic goals of a bank.

Table 6. Relationships between socially responsible Facebook disclosures and bank growth/performance (source: author's own calculations)

\begin{tabular}{|c|c|c|c|c|c|c|}
\hline & (1) & (2) & (3) & (4) & (5) & (6) \\
\hline $\begin{array}{l}\text { Dependent } \\
\text { variable: }\end{array}$ & DEPO $\triangle$ & LOAN $\Delta$ & ASSET $\Delta$ & NIM & R.LOSS & PROFIT \\
\hline \multirow{2}{*}{ SIZE } & $-0.0166^{\star}$ & -0.0110 & $-0.0149^{\star}$ & $-0.00218^{\star *}$ & $-2.36 \mathrm{e}-05$ & -0.0143 \\
\hline & $(0.00884)$ & $(0.0113)$ & $(0.00787)$ & $(0.000929)$ & $(0.00107)$ & $(0.0174)$ \\
\hline \multirow{2}{*}{ NIM } & $3.630^{* * *}$ & $4.477^{\star *}$ & $3.833^{\star * *}$ & & & \\
\hline & $(1.368)$ & (1.953) & $(1.332)$ & & & \\
\hline \multirow{2}{*}{ LOANS } & 0.0456 & -0.0269 & 0.0315 & $0.0171^{* * *}$ & 0.000883 & $0.144^{\star *}$ \\
\hline & $(0.0356)$ & $(0.0654)$ & $(0.0329)$ & $(0.00441)$ & $(0.00354)$ & $(0.0694)$ \\
\hline \multirow{2}{*}{ EQUITY } & $-1.519^{\star * *}$ & $-1.987^{\star * *}$ & $-1.539^{\star * *}$ & 0.0205 & -0.0278 & $-3.592^{* * *}$ \\
\hline & $(0.425)$ & $(0.664)$ & $(0.378)$ & $(0.0272)$ & $(0.0240)$ & $(0.394)$ \\
\hline \multirow{2}{*}{ PROFIT } & $-0.238^{\star * *}$ & $-0.387^{\star * *}$ & $-0.241^{* * *}$ & & & \\
\hline & $(0.0890)$ & $(0.132)$ & $(0.0868)$ & & & \\
\hline \multirow{2}{*}{ COSTS } & -0.0835 & -0.0989 & -0.0919 & -0.00917 & -0.0149 & 0.0618 \\
\hline & $(0.0707)$ & $(0.0936)$ & $(0.0639)$ & $(0.00870)$ & $(0.0103)$ & $(0.140)$ \\
\hline \multirow{2}{*}{ UNEMPL } & -0.00351 & 0.00891 & -0.000605 & 0.000922 & 0.00111 & 0.0197 \\
\hline & $(0.00916)$ & $(0.0112)$ & $(0.00844)$ & $(0.00108)$ & $(0.000875)$ & $(0.0146)$ \\
\hline \multirow{2}{*}{ POPUL } & $-0.0410^{\star * *}$ & $-0.0412^{\star *}$ & $-0.0453^{* * *}$ & $0.00322^{* *}$ & $0.00525^{\star * *}$ & $0.0446^{*}$ \\
\hline & $(0.0120)$ & $(0.0169)$ & $(0.0107)$ & $(0.00126)$ & $(0.00146)$ & $(0.0245)$ \\
\hline \multirow{2}{*}{$\begin{array}{l}\text { Socially } \\
\text { Responsible }\end{array}$} & -0.00340 & 0.00312 & -0.00502 & 0.000308 & -0.000765 & 0.0122 \\
\hline & $(0.00893)$ & $(0.0121)$ & $(0.00824)$ & $(0.00110)$ & $(0.00107)$ & $(0.0163)$ \\
\hline \multirow{2}{*}{ Constant } & $0.597^{* * *}$ & $0.607^{\star}$ & $0.571^{\star * *}$ & $0.0623^{* *}$ & 0.0165 & $0.882^{*}$ \\
\hline & $(0.225)$ & $(0.340)$ & $(0.199)$ & $(0.0257)$ & $(0.0280)$ & $(0.447)$ \\
\hline Banks & 108 & 108 & 108 & 108 & 108 & 108 \\
\hline R-squared & 0.264 & 0.168 & 0.284 & 0.249 & 0.183 & 0.605 \\
\hline
\end{tabular}

Note: Robust standard errors are presented in parentheses; ${ }^{*},{ }^{* *}$, and ${ }^{* * *}$ refer to statistical significance at the $10 \%, 5 \%$, and $1 \%$ levels, respectively. 
Table 7. Relationships between the content of SLBs' Facebook posts and bank growth/performance (source: author's own calculations)

\begin{tabular}{|c|c|c|c|c|c|c|c|c|}
\hline & (1) & (2) & (3) & (4) & (5) & (6) & (7) & (8) \\
\hline $\begin{array}{l}\text { Dependent } \\
\text { variable: }\end{array}$ & DEPO $\triangle$ & $\mathrm{DEPO} \Delta$ & DEPO $\triangle$ & DEPO $\Delta$ & DEPO $\triangle$ & DEPO $\triangle$ & $\mathrm{DEPO} \Delta$ & DEPO $\triangle$ \\
\hline $\begin{array}{l}\text { Regressor } \\
\text { describing } \\
\text { posts: }\end{array}$ & ADS & PROD & AWARD & CHARIT & SOCIAL & LOCAL & TECH & OTHER \\
\hline \multirow[t]{3}{*}{$\begin{array}{l}\text { Coefficient for } \\
\text { the regressor: }\end{array}$} & 0.0274 & -0.0149 & 0.0769 & $0.213^{* *}$ & -0.00273 & $-0.135^{\star \star}$ & 0.0248 & -0.000235 \\
\hline & $(0.0460)$ & $(0.0280)$ & $(0.0752)$ & $(0.0929)$ & $(0.0542)$ & $(0.0518)$ & $(0.108)$ & $(0.0446)$ \\
\hline & (9) & (10) & (11) & (12) & (13) & (14) & (15) & (16) \\
\hline $\begin{array}{l}\text { Dependent } \\
\text { variable: }\end{array}$ & LOAN $\Delta$ & LOAN $\Delta$ & LOAN $\Delta$ & LOAN $\Delta$ & LOAN $\Delta$ & LOAN $\Delta$ & LOAN $\Delta$ & LOAN $\Delta$ \\
\hline $\begin{array}{l}\text { Regressor } \\
\text { describing } \\
\text { posts: }\end{array}$ & ADS & PROD & AWARD & CHARIT & SOCIAL & LOCAL & TECH & OTHER \\
\hline \multirow[t]{3}{*}{$\begin{array}{l}\text { Coefficient for } \\
\text { the regressor: }\end{array}$} & -0.0478 & 0.00473 & -0.00697 & $0.171^{*}$ & 0.0308 & $-0.138^{*}$ & 0.200 & -0.00449 \\
\hline & \begin{tabular}{|l|}
$(0.0608)$ \\
\end{tabular} & \begin{tabular}{|l|}
$(0.0368)$ \\
\end{tabular} & $(0.130)$ & $(0.0961)$ & \begin{tabular}{|l|}
$(0.0640)$ \\
\end{tabular} & $(0.0765)$ & $(0.142)$ & $(0.0676)$ \\
\hline & (17) & (18) & (19) & (20) & (21) & (22) & (23) & (24) \\
\hline $\begin{array}{l}\text { Dependent } \\
\text { variable: }\end{array}$ & ASSET $\Delta$ & ASSET $\Delta$ & ASSET $\Delta$ & ASSET $\Delta$ & ASSET $\Delta$ & ASSET $\Delta$ & ASSET $\Delta$ & ASSET $\Delta$ \\
\hline $\begin{array}{l}\text { Regressor } \\
\text { describing } \\
\text { posts: }\end{array}$ & ADS & PROD & AWARD & CHARIT & SOCIAL & LOCAL & TECH & OTHER \\
\hline \multirow[t]{3}{*}{$\begin{array}{l}\text { Coefficient for } \\
\text { the regressor: }\end{array}$} & 0.00779 & -0.0126 & 0.0939 & $0.204^{* *}$ & -0.00294 & $-0.127^{* *}$ & 0.0129 & 0.00425 \\
\hline & $(0.0433)$ & $(0.0250)$ & $(0.0724)$ & $(0.0834)$ & $(0.0501)$ & $(0.0502)$ & $(0.0985)$ & $(0.0428)$ \\
\hline & (25) & (26) & (27) & (28) & (29) & (30) & (31) & $(32)$ \\
\hline $\begin{array}{l}\text { Dependent } \\
\text { variable: }\end{array}$ & NIM & NIM & NIM & NIM & NIM & NIM & NIM & NIM \\
\hline $\begin{array}{l}\text { Regressor } \\
\text { describing } \\
\text { posts: }\end{array}$ & ADS & PROD & AWARD & CHARIT & SOCIAL & LOCAL & TECH & OTHER \\
\hline \multirow[t]{3}{*}{$\begin{array}{l}\text { Coefficient for } \\
\text { the regressor: }\end{array}$} & $-0.0128^{*}$ & -0.00319 & $0.0144^{\star}$ & $0.0161^{\star}$ & $0.0112^{*}$ & -0.00116 & -0.00979 & $2.07 e-05$ \\
\hline & $(0.00700)$ & $(0.00379)$ & $(0.00827)$ & $(0.00825)$ & $(0.00583)$ & $(0.00587)$ & $(0.0103)$ & $(0.00463)$ \\
\hline & (33) & (34) & (35) & (36) & (37) & (38) & (39) & $(40)$ \\
\hline $\begin{array}{l}\text { Dependent } \\
\text { variable: }\end{array}$ & R.LOSS & R.LOSS & R.LOSS & R.LOSS & R.LOSS & R.LOSS & R.LOSS & R.LOSS \\
\hline $\begin{array}{l}\text { Regressor } \\
\text { describing } \\
\text { posts: }\end{array}$ & ADS & PROD & AWARD & CHARIT & SOCIAL & LOCAL & TECH & OTHER \\
\hline
\end{tabular}


End of Table 7

\begin{tabular}{|l|c|c|c|c|c|c|c|c|}
\hline & $(33)$ & $(34)$ & $(35)$ & $(36)$ & $(37)$ & $(38)$ & $(39)$ & $(40)$ \\
\hline $\begin{array}{l}\text { Coefficient for } \\
\text { the regressor: }\end{array}$ & 0.000364 & $0.00482^{*}$ & $-0.021^{\star * *}$ & $-0.0144^{* *}$ & 0.000838 & -0.00721 & -0.0152 & 0.00440 \\
\hline & $(0.00696)$ & $(0.00290)$ & $(0.00643)$ & $(0.00656)$ & $(0.00565)$ & $(0.00553)$ & $(0.00979)$ & $(0.00470)$ \\
\hline $\begin{array}{l}\text { Dependent } \\
\text { variable: }\end{array}$ & PROFIT & PROFIT & PROFIT & PROFIT & PROFIT & PROFIT & PROFIT & PROFIT \\
\hline $\begin{array}{l}\text { Regressor } \\
\text { describing } \\
\text { posts: }\end{array}$ & ADS & PROD & AWARD & CHARIT & SOCIAL & LOCAL & TECH & OTHER \\
\hline $\begin{array}{l}\text { Coefficient for } \\
\text { the regressor: }\end{array}$ & -0.0824 & -0.0328 & -0.0428 & 0.111 & $0.232^{* * *}$ & -0.0665 & -0.198 & -0.0228 \\
\hline \multicolumn{1}{|c|}{$(4)$} & $(43)$ & $(44)$ & $(45)$ & $(46)$ & $(47)$ & $(48)$ \\
\hline
\end{tabular}

Note: For brevity, coefficients for the control variables (SIZE, NIM, LOANS, EQUITY, PROFIT, COSTS, UNEMPL, and POPUL), constant term, and R-squared are not reported. Robust standard errors are presented in parentheses; ${ }^{*},{ }^{* *}$, and ${ }^{* * *}$ refer to statistical significance at the $10 \%, 5 \%$, and $1 \%$ levels, respectively.

\subsection{Robustness checks}

The results presented in Tables 6 and 7 provide evidence for an existing link between specific types of social media activities and bank growth or performance. Nevertheless, they do not prove a causal relationship. Specifically, one may argue against the impact of Facebook disclosures on bank growth or performance due to potential endogeneity and reverse causation. To be more precise, it cannot be ruled out that increased growth or performance are predecessors of received thanks or awards and undertaken charitable or social activities that are reported on a bank's Facebook profile. Therefore, to address those concerns, an additional robustness check is constructed. Instead of using the original cross-section dataset with values averaged over the 2010-2017 period, a panel sample with bank-year observations is constructed; that is, each bank-year observation receives the values of dependent and explanatory variables that were employed in Eq. (2). Each bank-year observation gets the share of Facebook posts of each type out of all posts published by a bank in a given year. Then, dynamic panel regression models are employed and, specifically, the GMM-SYS estimation procedure proposed by Blundell and Bond (1998). It allows for the inclusion of potentially endogenous variables among the regressors. Thus, it is possible to efficiently control for the potential endogeneity in the relationship between Facebook disclosures and bank growth or performance. The general construction of the panel models is illustrated by Eq. (3):

$$
E C O N_{\underline{i t}}=\mathrm{f}\left(P E R F_{i, t-1} ; F I N_{i, t-1} ; E N V_{i t} ; F C_{i t} ; \text { year dummies }\right) \text {, }
$$

where $E C O N_{i t}$ describes the $i$-th bank's growth (DEPOA, LOANA, ASSETA) or its performance (NIM, R.LOSS, PROFIT) in year $t$, the set of lagged variables $F_{i, t-1}$ controls for the $i$-th bank's specificity in year $t-1$ (a lagged dependent variable, SIZE, LOANS, EQUITY, and COSTS in all regressions, and additionally PROFIT and NIM in DEPO $\Delta$, LOAN $\Delta$, 
ASSET $\Delta$ models), and $E N V_{i t}$ reflects the $i$-th bank's local environment in year $t$ (UNEMPL and POPUL). Finally, specification employs one variable from the $F C_{i t}$ set that describes the thematic content of the $i$-th bank's Facebook activity in year $t$. It should be noted that in the regressions treat each of the $F C_{i t}$ variables as endogenous and a lagged dependent variable as only sequentially exogenous. The validity of the instruments is tested with the ArellanoBond test and the Hansen test. ${ }^{4}$

Table 8 presents the results of the dynamic panel estimations. For brevity, only the coefficients for the regressors that describe the categories of a bank's Facebook posts are reported. The tabulated results lead to similar conclusions as the outcomes from Table 7. Social media disclosures on CSR have a positive and statistically significant impact on bank growth or performance; that is, an increase in the share of posts on charitable activities draws more deposits $(D E P O \triangle)$, ensures a bank's growth in terms of its assets (ASSETA), and stimulates net interest margins (NIM) and profitability (PROFIT). In comparison to posts concerning charitable activities, social media disclosures on other social issues (SOCIAL) have relatively less positive influence on deposits (DEPO $)$ ) and assets (ASSET $\triangle)$, and the coefficients for the variable that describes the share of posts with local news (LOCAL) are consistently statistically insignificant. It is worth stressing that dynamic panel estimations provide new insight into the effect exerted by posts with product offers. Whereas OLS estimations generated negative but statistically insignificant coefficients for the PROD variable in the DEPO $\triangle$ and ASSET $\triangle$ specifications, the coefficients from the GMM-SYS regressions are negative but statistically significant in the respective specifications. These outcomes suggest that excessive product marketing in social media does not pay off and may deter customers from engaging with a bank.

Table 8. GMM panel estimations. Relationships between the content of SLBs' Facebook posts and bank growth/performance (source: author's own calculations)

\begin{tabular}{|l|c|c|c|c|c|c|c|c|}
\hline & $(1)$ & $(2)$ & $(3)$ & $(4)$ & $(5)$ & $(6)$ & $(7)$ & $(8)$ \\
\hline $\begin{array}{l}\text { Dependent } \\
\text { variable: }\end{array}$ & DEPO $\Delta$ & DEPO $\Delta$ & DEPO $\Delta$ & DEPO $\Delta$ & DEPO $\Delta$ & DEPO $\Delta$ & DEPO $\Delta$ & DEPO $\Delta$ \\
\hline $\begin{array}{l}\text { Regressor } \\
\text { describing } \\
\text { posts: }\end{array}$ & ADS & PROD & AWARD & CHARIT & SOCIAL & LOCAL & TECH & OTHER \\
\hline $\begin{array}{l}\text { Coefficient } \\
\text { for the } \\
\text { regressor: }\end{array}$ & 0.0603 & $-0.113^{* * *}$ & 0.113 & $0.313^{* *}$ & $0.139^{* *}$ & 0.0159 & -0.127 & -0.00273 \\
\hline$(0.0535)$ & $(0.0390)$ & $(0.144)$ & $(0.136)$ & $(0.0554)$ & $(0.0797)$ & $(0.0868)$ & $(0.0810)$ \\
\hline $\begin{array}{l}\text { Dependent } \\
\text { variable: }\end{array}$ & LOAN $\Delta$ & LOAN $\Delta$ & LOAN $\Delta$ & LOAN $\Delta$ & LOAN $\Delta$ & LOAN $\Delta$ & LOAN $\Delta$ & LOAN $\Delta$ \\
\hline $\begin{array}{l}\text { Regressor } \\
\text { describing } \\
\text { posts: }\end{array}$ & ADS & PROD & AWARD & CHARIT & SOCIAL & LOCAL & TECH & OTHER \\
\hline
\end{tabular}

\footnotetext{
${ }^{4}$ It is worth stressing that all models possess favorable econometric properties. Namely, there are no grounds for the rejection of the null hypotheses in the case of the AR(2) and Hansen tests. Although the results of these diagnostics tests are not reported for brevity, they are available upon request.
} 
End of Table 8

\begin{tabular}{|c|c|c|c|c|c|c|c|c|}
\hline & (9) & (10) & (11) & (12) & (13) & (14) & (15) & (16) \\
\hline \multirow{3}{*}{$\begin{array}{l}\text { Coefficient } \\
\text { for the } \\
\text { regressor: }\end{array}$} & 0.0183 & -0.0505 & 0.0958 & 0.173 & -0.0228 & -0.0445 & $0.319^{* * *}$ & -0.0470 \\
\hline & $(0.0655)$ & $(0.0432)$ & $(0.168)$ & $(0.175)$ & $(0.0737)$ & $(0.0866)$ & $(0.0965)$ & $(0.0842)$ \\
\hline & (17) & (18) & (19) & (20) & (21) & (22) & (23) & (24) \\
\hline $\begin{array}{l}\text { Dependent } \\
\text { variable: }\end{array}$ & ASSET $\Delta$ & ASSET $\Delta$ & ASSET $\Delta$ & ASSET $\triangle$ & ASSET $\Delta$ & ASSET $\Delta$ & ASSET $\Delta$ & ASSET $\Delta$ \\
\hline $\begin{array}{l}\text { Regressor } \\
\text { describing } \\
\text { posts: }\end{array}$ & ADS & PROD & AWARD & CHARIT & SOCIAL & LOCAL & $\mathrm{TECH}$ & OTHER \\
\hline \multirow{3}{*}{$\begin{array}{l}\text { Coefficient } \\
\text { for the } \\
\text { regressor: }\end{array}$} & 0.0731 & $-0.120^{\star * *}$ & 0.0930 & $0.202^{*}$ & $0.108^{\star *}$ & 0.0197 & $-0.154^{\star \star}$ & -0.0275 \\
\hline & $(0.0500)$ & $(0.0390)$ & $(0.138)$ & $(0.111)$ & $(0.0507)$ & $(0.0762)$ & $(0.0688)$ & $(0.0858)$ \\
\hline & $(25)$ & (26) & (27) & $(28)$ & $(29)$ & $(30)$ & $(31)$ & $(32)$ \\
\hline $\begin{array}{l}\text { Dependent } \\
\text { variable: }\end{array}$ & NIM & NIM & NIM & NIM & NIM & NIM & NIM & NIM \\
\hline $\begin{array}{l}\text { Regressor } \\
\text { describing } \\
\text { posts: }\end{array}$ & ADS & PROD & AWARD & CHARIT & SOCIAL & LOCAL & $\mathrm{TECH}$ & OTHER \\
\hline \multirow{3}{*}{$\begin{array}{l}\text { Coefficient } \\
\text { for the } \\
\text { regressor: }\end{array}$} & 0.00342 & 0.00206 & -0.00409 & -0.00335 & -0.00319 & 0.00119 & -0.00338 & 0.000943 \\
\hline & $(0.00358)$ & $(0.00178)$ & $(0.00547)$ & $(0.00517)$ & $(0.00370)$ & $(0.00325)$ & $(0.00232)$ & $(0.00417)$ \\
\hline & $(33)$ & (34) & $(35)$ & $(36)$ & $(37)$ & $(38)$ & $(39)$ & $(40)$ \\
\hline $\begin{array}{l}\text { Dependent } \\
\text { variable: }\end{array}$ & R.LOSS & R.LOSS & R.LOSS & R.LOSS & R.LOSS & R.LOSS & R.LOSS & R.LOSS \\
\hline $\begin{array}{l}\text { Regressor } \\
\text { describing } \\
\text { posts: } \\
\end{array}$ & ADS & PROD & AWARD & CHARIT & SOCIAL & LOCAL & $\mathrm{TECH}$ & OTHER \\
\hline \multirow[t]{3}{*}{$\begin{array}{l}\text { Coefficient } \\
\text { for the } \\
\text { regressor: }\end{array}$} & -0.00197 & 0.00491 & -0.0107 & $-0.0258^{\star}$ & -0.000849 & 0.00208 & -0.00350 & -0.00826 \\
\hline & $(0.00531)$ & $(0.00483)$ & $(0.0136)$ & $(0.0134)$ & $(0.00571)$ & $(0.00971)$ & $(0.00438)$ & $(0.00852)$ \\
\hline & $(41)$ & $(42)$ & (43) & (44) & $(45)$ & (46) & $(47)$ & $(48)$ \\
\hline $\begin{array}{l}\text { Dependent } \\
\text { variable: }\end{array}$ & PROFIT & PROFIT & PROFIT & PROFIT & PROFIT & PROFIT & PROFIT & PROFIT \\
\hline $\begin{array}{l}\text { Regressor } \\
\text { describing } \\
\text { posts: }\end{array}$ & ADS & PROD & AWARD & CHARIT & SOCIAL & LOCAL & $\mathrm{TECH}$ & OTHER \\
\hline \multirow[t]{2}{*}{$\begin{array}{l}\text { Coefficient } \\
\text { for the } \\
\text { regressor: }\end{array}$} & -0.0297 & 0.0407 & $0.182^{*}$ & $0.136^{*}$ & -0.0428 & -0.0758 & -0.0250 & -0.0627 \\
\hline & $(0.0285)$ & $(0.0271)$ & $(0.104)$ & $(0.0736)$ & $(0.0371)$ & $(0.0475)$ & $(0.0350)$ & $(0.0550)$ \\
\hline
\end{tabular}

Note: For brevity, the coefficients for the control variables (a lagged dependent variable, SIZE, NIM, LOANS, EQUITY, PROFIT, COSTS, contemporary UNEMPL, and POPUL), constant term, and year dummies are not reported. Robust standard errors are presented in parentheses; ${ }^{*},{ }^{* *}$, and ${ }^{* * *}$ refer to statistical significance at the $10 \%, 5 \%$, and $1 \%$ levels, respectively. 


\section{Conclusions}

The study investigated the thematic content of posts published by Polish SLBs and its impact on Facebook users' interest, as well as SLBs' economic outcomes. The estimation results show that all CSR disclosures by a bank have a positive impact on Facebook users' interest, although not all play a comparably important role within this respect. In contrast, only posts with selected thematic areas of a bank's social responsibility (charitable activities or a bank's social life) associate with an SLB's increased growth or performance. These findings have managerial implications. Namely, they suggest that drawing attention of Facebook users is a different challenge than converting this attention into bank growth or increased performance. Although Facebook disclosures on all socially responsible issues consistently boost Facebook users' interest in posts published by a bank, disclosures on social responsibility in general terms do not automatically lead to economic outcomes. At the same time, it is worth stressing that CSR and economic effects do not contradict, and SLBs can successfully employ social media in their unique and traditional business strategies, which combine strictly commercial functions with support to their local communities. Although SLBs try to imitate commercial banks in the implementation of new communication tools, it does not seem to be a direct route toward their commercialization and the loss of SLBs' unique identity. Although time period covered in the study ends in 2017, it can be argued that the investigations and their conclusions have lost nothing of their topicality. The social media presence of small local banks is still underdeveloped in comparison to their large commercial peers, and the social media adoption in general terms is still accelerating. Namely, the number of social media users in Poland increased by 2.5 million between 2020 and $2021(+11 \%)$ and covers $68.5 \%$ of the total population in January 2021 (Kemp, 2021). In addition, nearly $90 \%$ of social media users were active Facebook users at the beginning of 2021 .

The study has one main shortcoming, which is determined by the scope of SLBs' Facebook activities and, thus, by the scope of data that can be used within the research. It should be noted that social media is still a new and innovative communication channel for SLBs. The median value of posts per bank between 2010 and 2017 in the sample is 177 , but there are still some entities with a relatively minor Facebook presence, as a quarter of the banks published less than 65 posts in the analyzed period. The limited number of banks that apply an active social media policy poses a challenge from an econometric point of view, as it forces the researcher to thoroughly rethink the definition of variables and reasonably handle the number of explanatory variables in regression models. Additionally, it reduces the possibility of preparing an in-depth analysis of the impact of various Facebook disclosures conditionally on other factors related to a bank's specificity or the competition it faces in its local market. Nevertheless, the developing nature of SLBs' social media activities should eliminate, or at least reduce, this limitation in the near future. This process is expected to open future research possibilities, including investigations of the banks' activities in other social media or collecting some additional data from individuals that reacted on Facebook posts to verify their intentions to use some service provided by the bank. 


\section{Acknowledgements}

The preliminary version of this manuscript, titled "Popularity in social media and company growth: Evidence for local banks", was presented at the International Scientific Conference "Contemporary Issues in Business, Management and Economics Engineering" in Vilnius, Lithuania (May 9-10, 2019). The Authors would like to thank the conference participants, anonymous reviewers and the Editor for their insightful comments which helped to improve the study.

\section{Funding}

This work was supported by the Polish National Science Center (Narodowe Centrum Nauki) under Grant 2017/25/B/HS4/00887, titled "Relacja przedsiębiorstwa z bankiem i jej ekonomiczne konsekwencje" ("Company and its bank: The relationship and its economic consequences").

\section{References}

Adjei, M. T., Noble, S. M., \& Noble, C. H. (2010). The influence of $\mathrm{C}_{2} \mathrm{C}$ communications in online brand communities on customer purchase behavior. Journal of the Academy of Marketing Science, 38, 634-653. https://doi.org/10.1007/s11747-009-0178-5

Ailawadi, K. L., Neslin, S. A., Luan, Y. J., \& Taylor, G. A. (2014). Does retailer CSR enhance behavioral loyalty? A case for benefit segmentation. International Journal of Research in Marketing, 31(2), 156-167. https://doi.org/10.1016/j.ijresmar.2013.09.003

Al Mubarak, Z., Hamed, A. B., \& Al Mubarak, M. (2018). Impact of corporate social responsibility on bank's corporate image. Social Responsibility Journal, 15(5), 710-722. https://doi.org/10.1108/SRJ-01-2018-0015

Anderson, J. C., \& Frankle, A. W. (1980). Voluntary social reporting: An iso-beta portfolio analysis. Accounting Review, 55, 467-479.

Appel, G., Grewal, L., Hadi, R., \& Stephen, A. T. (2020). The future of social media in marketing. Journal of the Academy of Marketing Science, 48, 79-95. https://doi.org/10.1007/s11747-019-00695-1

Blundell, R.W., \& Bond, S. R. (1998). Initial conditions and moment restrictions in dynamic panel data models. Journal of Econometrics, 87(1), 115-143. https://doi.org/10.1016/S0304-4076(98)00009-8

Bolton, B. J. (2013). Corporate social responsibility and bank performance. https://doi.org/10.2139/ssrn.2277912

Bolton, R. N. (2011). Customer engagement: Opportunities and challenges for organizations. Journal of Service Research, 14(3), 272-274. https://doi.org/10.1177/1094670511414582

Bonsón, E., Torres, L., Rayo, S., \& Flores, F. (2012). Local e-government 2.0: Social media and corporate transparency in municipalities. Government Information Quarterly, 29(2), 123-132. https://doi.org/10.1016/j.giq.2011.10.001

Cao, Y., Ajjan, H., Hong, P., \& Le, T. (2018). Using social media for competitive business outcomes: An empirical study of companies in China. Journal of Advances in Management Research, 15(2), 211-235. https://doi.org/10.1108/JAMR-05-2017-0060

Carrasco, I. (2007). Corporate social responsibility, values, and cooperation. International Advances in Economic Research, 13, 454-460. https://doi.org/10.1007/s11294-007-9110-2

Cawsey, T. \& Rowley, J. (2016). Social media brand building strategies in B2B companies. Marketing Intelligence \& Planning, 34(6), 754-776. https://doi.org/10.1108/MIP-04-2015-0079 
Chiang, C. H., \& Tseng, K. C. (2017). The influence of fan pages on consumer purchase intention: Liking behavior as a moderator. Journal of Marketing Management, 5, 44-59.

Cochran, P. L., \& Wood, R. A. (1984). Corporate social responsibility and financial performance. Academy of Management Journal, 27(1), 42-56. https://doi.org/10.5465/255956

Cornelius, N., Todres, M., Janjuha-Jivraj, S., Woods, A., \& Wallace, J. (2008). Corporate social responsibility and the social enterprise. Journal of Business Ethics, 81, 355-370. https://doi.org/10.1007/s10551-007-9500-7

Courchane, M., Nickerson, D., \& Sullivan, R. (2002). Investment in internet banking as a real option: Theory and tests. Journal of Multinational Financial Management, 12(4-5), 347-363. https://doi.org/10.1016/S1042-444X(02)00015-4

Creyer, E. H. (1997). The influence of firm behavior on purchase intention: Do consumers really care about business ethics? Journal of Consumer Marketing, 14(6), 421-432. https://doi.org/10.1108/07363769710185999

Cvijikj, I. P., \& Michahelles, F. (2011). A case study of the effects of moderator posts within a Facebook brand page. In A. Datta, S. Shulman, B. Zheng., S. D. Lin, A. Sun, \& E. P. Lim (Eds.), Lecture notes in computer science: Vol. 6984. Social informatics. SocInfo 2011 (pp. 161-170). Springer. https://doi.org/10.1007/978-3-642-24704-0_21

Dahnil, M. I., Marzuki, K. M., Langgat, J., \& Fabeil, N. F. (2014). Factors influencing SMEs adoption of social media marketing. Procedia - Social and Behavioral Sciences, 148, 119-126. https://doi.org/10.1016/j.sbspro.2014.07.025

Davis, K. (1973). The case for and against business assumption of social responsibilities. Academy of Management Journal, 16(2), 312-322. https://doi.org/10.5465/255331

van Doorn, J., Onrust, M., Verhoef, P.C., \& Bügel, M. (2017). The impact of corporate social responsibility on customer attitudes and retention - the moderating role of brand success indicators. Marketing Letters, 28, 607-619. https://doi.org/10.1007/s11002-017-9433-6

Drumwright, M. E. (1994). Socially responsible organizational buying: Environmental concern as a noneconomic buying criterion. Journal of Marketing, 58(3), 1-19. https://doi.org/10.1177/002224299405800301

Du, S., Bhattacharya, C. B., \& Sen, S. (2010). Maximizing business returns to corporate social responsibility (CSR): The role of CSR communication. International Journal of Management Reviews, 12(1), 8-19. https://doi.org/10.1111/j.1468-2370.2009.00276.x

Durkin, M., McGowan, P., \& Murray, L. (2014). Perspectives on the potential for social media to improve communication in small business-bank relationships. Entrepreneurship and Innovation, 15(4), 251-264. https://doi.org/10.5367/ijei.2014.0163

Durkin, M., Mulholland, G., \& McCartan, A. (2015). A socio-technical perspective on social media adoption: a case from retail banking. International Journal of Bank Marketing, 33(7), 944-962. https://doi.org/10.1108/IJBM-01-2015-0014

Edelman, D. (2010). Branding in the digital age: you're spending your money in all the wrong places. Harvard Business Review, 88, 62-69.

European Association of Co-operative Banks. (2020, October). Co-operative banks' engagement to green and sustainable finance. http://www.eacb.coop/en/news/green-and-sustainable-finance/new-studyco-operative-banks-rsquo-engagement-to-green-and-sustainable-finance.html

Farshid, M., Plangger, K., \& Nel, D. (2011). The social media faces of major global financial service brands. Journal of Financial Services Marketing, 16, 220-229. https://doi.org/10.1057/fsm.2011.19

Filip, D., Jackowicz, K., \& Kozłowski, Ł. (2017). Influence of internet and social media presence on small, local bank's market power. Baltic Journal of Economics, 17(2), 190-214. https://doi.org/10.1080/1406099X.2017.1376856

Fombrun, C. (2005). Building corporate reputation through CSR initiatives: evolving standards. Corporate Reputation Review, 8, 7-12. https://doi.org/10.1057/palgrave.crr.1540235 
Gallaugher, J., \& Ransbotham, S. (2010). Social media and customer dialog management at Starbucks. MIS Quarterly Executive, 9, 197-212.

Giagnocavo, C., Gerez, S., \& Sforzi, J. (2012). Cooperative bank strategies for social-economic problem solving: Supporting social enterprise and local development. Annals of Public and Cooperative Economics, 83(3), 281-315. https://doi.org/10.1111/j.1467-8292.2012.00464.x

Gong, T. (2018). Customer brand engagement behavior in online brand communities. Journal of Services Marketing, 32(3), 286-299. https://doi.org/10.1108/JSM-08-2016-0293

Guesalaga, R. (2016). The use of social media in sales: Individual and organizational antecedents, and the role of customer engagement in social media. Industrial Marketing Management, 54, 71-79. https://doi.org/10.1016/j.indmarman.2015.12.002

Guillamón, A. M., Ríos, B., Gesuele, C., \& Metallo, C. (2016). Factors influencing social media use in local governments: The case of Italy and Spain María-Dolores. Government Information Quarterly, 33(3), 460-471. https://doi.org/10.1016/j.giq.2016.06.005

Hirigoyen, G., \& Poulain-Rehm, T. (2015). Relationships between Corporate Social Responsibility and financial performance: What is the Causality? Journal of Business \& Management, 4(1), 18-43.

Hsu, L. \& Lawrence, B. (2016). The role of social media and brand equity during a product recall crisis: A shareholder value perspective. International Journal of Research in Marketing, 33(1), 59-77. https://doi.org/10.1016/j.ijresmar.2015.04.004

Jackowicz, K., Kozłowski, Ł., Kuchciak, I., \& Marcinkowska, M. (2020). Local banks in social media. Determinants and consequences. Economic Research-Ekonomska Istraživanja, 33(1), 3356-3384. https://doi.org/10.1080/1331677X.2020.1773892

Kaplan, A. M., \& Haenlein, M. (2010). Users of the world unite! The challenges and opportunities of Social Media. Business Horizons, 53(1), 59-68. https://doi.org/10.1016/j.bushor.2009.09.003

Kaufman, L., \& Rousseeuw, P. (1990). Finding groups in data: An introduction to cluster analysis. John Wiley and Sons. https://doi.org/10.1002/9780470316801

Kemp, S. (2021). Digital 2021: Poland. Datareportal. https://datareportal.com/reports/digital-2021-poland

Kim, S., Koh, Y., Cha, J., \& Lee, S. (2015a). Effects of social media on firm value for U.S. restaurant companies. International Journal of Hospitality Management, 49, 40-46. https://doi.org/10.1016/j.ijhm.2015.05.006

Kim, G., Lim, H., \& Brymer, R. A. (2015b). The effectiveness of managing social media on hotel performance. International Journal of Hospitality Management, 44, 165-171. https://doi.org/10.1016/j.ijhm.2014.10.014

Laroche, M., Habibi, M. R., \& Richard, M. O. (2013). To be or not to be in social media: how brand loyalty is affected by social media? International Journal of Information Management, 33(1), 76-82. https://doi.org/10.1016/j.ijinfomgt.2012.07.003

Laroche, M., Habibi, M. R., Richard, M. O., \& Sankaranarayanan, R. (2012). The effects of social media based brand communities on brand community markers, value creation practices, brand trust and brand loyalty. Computers in Human Behavior, 28(5), 1755-1767. https://doi.org/10.1016/j.chb.2012.04.016

Larsson, A., \& Viitaoja, Y. (2017). Building customer loyalty in digital banking: A study of bank staff's perspectives on the challenges of digital CRM and loyalty. International Journal of Bank Marketing, 35(6), 858-877. https://doi.org/10.1108/IJBM-08-2016-0112

Lev-On, A., \& Steinfeld, N. (2015). Local engagement online: Municipal Facebook pages as hubs of interaction. Government Information Quarterly, 32(3), 299-307. https://doi.org/10.1016/j.giq.2015.05.007

Lichtenstein, D. R., Drumwright, M. E., \& Braing, B. M. (2004). The effect of corporate social responsibility on customer donations to corporate-supported nonprofits. Journal of Marketing, 68(4), 16-32. https://doi.org/10.1509/jmkg.68.4.16.42726 
Lii, Y., \& Lee, M. (2012). Doing right leads to doing well: When the type of CSR and reputation interact to affect consumer evaluations of the firm. Journal of Business Ethics, 105, 69-81. https://doi.org/10.1007/s10551-011-0948-0

Lin, W. L., Law, S. H., Ho, J. A., \& Sambasivan, M. (2019). The causality direction of the corporate social responsibility - Corporate financial performance Nexus: Application of Panel Vector Autoregression approach. The North American Journal of Economics and Finance, 48, 401-418. https://doi.org/10.1016/j.najef.2019.03.004

Lipsman, A., Mudd, G., Rich, M., \& Bruich, S. (2012). The power of "like": How brands reach (and influence) fans through social-media marketing. Journal of Advertising Research, 52, 40-52. https://doi.org/10.2501/JAR-52-1-040-052

Lombart, C., \& Louis, D. (2014). A study of the impact of Corporate Social Responsibility and price image on retailer personality and consumers' reactions-satisfaction, trust and loyalty to the retailer. Journal of Retailing and Consumer Services, 21(4), 630-642. https://doi.org/10.1016/j.jretconser.2013.11.009

Lys, T., Naughton, J. P., \& Wang, C. (2015). Signaling through corporate accountability reporting. Journal of Accounting and Economics, 60(1), 56-72. https://doi.org/10.1016/j.jacceco.2015.03.001

Mangold, W. G., \& Faulds, D. J. (2009). Social media: The new hybrid element of the promotion mix. Business Horizons, 52(4), 357-365. https://doi.org/10.1016/j.bushor.2009.03.002

Marin, L., \& Salvador, R. (2007). "I Need You Too!" Corporate identity attractiveness for consumers and the role of social responsibility. Journal of Business Ethics, 71, 245-260.

https://doi.org/10.1007/s10551-006-9137-y

Mercadé-Melé, P., Molinillo, S., Fernández-Morales, A., \& Porcu, L. (2018). CSR activities and consumer loyalty: The effect of the type of publicizing medium. Journal of Business Economics and Management, 19(3), 431-455. https://doi.org/10.3846/jbem.2018.5203

Michaelidou, N., Siamagka, N. T., \& Christodoulides, G. (2011). Usage, barriers and measurement of social media marketing: An exploratory investigation of small and medium B2B brands. Industrial Marketing Management, 40(7), 1153-1159. https://doi.org/10.1016/j.indmarman.2011.09.009

Mohr, L. A., \& Webb, D. J. (2005). The effects of corporate social responsibility and price on consumer responses. Journal of Consumer Affairs, 39(1), 121-147. https://doi.org/10.1111/j.1745-6606.2005.00006.x

Naeem, M. (2020). The role of social media to generate social proof as engaged society for stockpiling behaviour of customers during Covid-19 pandemic. Qualitative Market Research (ahead-of-print). https://doi.org/10.1108/QMR-04-2020-0050

Nowacka, A. (2016). Postrzeganie społecznej odpowiedzialności biznesu w bankach spółdzielczych przez ich klientów. Ekonomia Społeczna, 2, 60-70. https://doi.org/10.15678/ES.2016.2.05

Öberseder, M., Schlegelmilch, B., \& Murphy, P. E. (2013). CSR practices and consumer perceptions. Journal of Business Research, 66(10), 1839-1851. https://doi.org/10.1016/j.jbusres.2013.02.005

Ordenes, F. V., Grewal, D., Ludwig, S., De Ruyter, K., Mahr, D., \& Wetzels, M. (2019). Cutting through content clutter: How speech and image acts drive consumer sharing of social media brand messages. Journal of Consumer Research, 45(5), 988-1012. https://doi.org/10.1093/jcr/ucy032

Orlitzky, M., Schmidt, F. L., \& Rynes, S. L. (2003). Corporate social and financial performance: A meta-analysis. Organization Studies, 24(3), 403-441. https://doi.org/10.1177/0170840603024003910

Ozdora-Aksaka, E., \& Atakan-Duman, S. (2015). The online presence of Turkish banks: Communicating the softer side of corporate identity. Public Relations Review, 41(1), 119-128.

https://doi.org/10.1016/j.pubrev.2014.10.004

Paniagua, J., \& Sapena, J. (2014). Business performance and social media: Love or hate? Business Horizons, 57(6), 719-728. https://doi.org/10.1016/j.bushor.2014.07.005 
Pérez, A., \& Del Bosque, I. R. (2015). Customer responses to the CSR of banking companies. Journal of Product \& Brand Management, 24(5), 481-493. https://doi.org/10.1108/JPBM-12-2014-0759

Plangger, K. (2012). The power of popularity: How the size of a virtual community adds to firm value. Journal of Public Affairs, 12(2), 145-153. https://doi.org/10.1002/pa.1416

Polish Financial Supervision Authority. (2019). Informacja o sytuacji banków spółdzielczych $i$ zrzeszajacych $w 2018$ roku [Information about the situation of cooperative banks and their affiliating entities in 2018]. https://www.knf.gov.pl/knf/pl/komponenty/img/Informacja_o_sytuacji_bankow_ spoldzielczych_2018_65698.pdf

Polychronidoua, P., Ioannidoua, E., Kipourosa, A., Tsourgiannisb, L., \& Simet, G. F. (2014). Corporate Social Responsibility in Greek banking sector - an empirical research. Procedia Economics and Finance, 9, 193-199. https://doi.org/10.1016/S2212-5671(14)00020-3

Ponte, E. B., Carvajal-Trujillo, E., \& Escobar-Rodríguez, T. (2015). Influence of trust and perceived value on the intention to purchase travel online: Integrating the effects of assurance on trust antecedents. Tourism Management, 47, 286-302. https://doi.org/10.1016/j.tourman.2014.10.009

Porter, M. E., \& Kramer, M. R. (2006). The link between competitive advantage and corporate social responsibility. Harvard Business Review, 84, 78-92.

Pozza, I. D. (2014). Multichannel management gets "social". European Journal of Marketing, 48(7-8), 1274-1295. https://doi.org/10.1108/EJM-10-2012-0598

Preston, L. E., \& O’Bannon, D. P. (1997). The corporate social-financial performance relationship: A typology and analysis. Business and Society, 36(4), 419-429. https://doi.org/10.1177/000765039703600406

Rimkuniené, D., \& Zinkeviciute, V. (2014). Social media in communication of temporary organisations: Role, needs, strategic perspective. Journal of Business Economics and Management, 15(5), 899-914. https://doi.org/10.3846/16111699.2014.938360

Ruostesaari, L., \& Troberg, E. (2016). Differences in social responsibility toward youth - A case study based comparison of cooperatives and corporations. Journal of Co-operative Organization and Management, 4(1), 42-51. https://doi.org/10.1016/j.jcom.2016.03.001

Salehzadeh, R., Khazaei Pool, J. K., \& Najafabadi, A. H. J. (2018). Exploring the relationship between corporate social responsibility, brand image and brand equity in Iranian banking industry. Journal of Islamic Accounting and Business Research, 9(2), 106-118.

https://doi.org/10.1108/JIABR-11-2014-0041

Sheth, J. (2020). Impact of Covid-19 on consumer behavior: Will the old habits return or die? Journal of Business Research, 117, 280-283. https://doi.org/10.1016/j.jbusres.2020.05.059

Sen, S., \& Bhattacharya, C. B. (2001). Does doing good always lead to doing better? Consumer reactions to corporate social responsibility. Journal of Marketing Research, 38(2), 225-243. https://doi.org/10.1509/jmkr.38.2.225.18838

Sen, S., Bhattacharya, C. B., \& Korschun, D. (2006). The role of corporate social responsibility in strengthening multiple stakeholder relationships: A field experiment. Journal of Academy of Marketing Science, 34, 158-166. https://doi.org/10.1177/0092070305284978

Servaes, H., \& Tamayo, A. (2013). The impact of corporate social responsibility on firm value: the role of customer awareness? Management Science, 59(5), 1045-1061.

https://doi.org/10.1287/mnsc.1120.1630

Siamagka, N.-T., Christodoulides, G., Michaelidou, N., \& Valvi, A. (2015). Determinants of social media adoption by B2B organizations. Industrial Marketing Management, 51, 89-99. https://doi.org/10.1016/j.indmarman.2015.05.005

Silver, L., \& Vegholm, F. (2009). The dyadic bank-SME relationship. Journal of Small Business and Enterprise Development, 16(4), 615-627. https://doi.org/10.1108/14626000911000956 
Siueia, T. T., Wang, J., \& Deladem, T. G. (2019). Corporate Social Responsibility and financial performance: A comparative study in the Sub-Saharan Africa banking sector. Journal of Cleaner Production, 226, 658-668. https://doi.org/10.1016/j.jclepro.2019.04.027

Swani, K., \& Milne, G. R. (2017). Evaluating Facebook brand content popularity for service versus goods offerings. Journal of Business Research, 79, 123-133. https://doi.org/10.1016/j.jbusres.2017.06.003

Swani, K., Milne, G., \& Brown, B. P. (2013). Spreading the word through likes on Facebook: Evaluating the message strategy effectiveness of Fortune 500 companies. Journal of Research in Interactive Marketing, 7(4), 269-294. https://doi.org/10.1108/JRIM-05-2013-0026

Tang, C., Mehl, M. R., Eastlick, M. A., He, W., \& Card, N. A. (2016). A longitudinal exploration of the relations between electronic word-of-mouth indicators and firms' profitability: Findings from the banking industry. International Journal of Information Management, 36(6), 1124-1132. https://doi.org/10.1016/j.ijinfomgt.2016.03.015

Thong, J. Y. L., \& Yap, C. S. (1995). CEO characteristics, organizational characteristics and information technology adoption in small businesses. Omega the International Journal of Management Science, 23(4), 429-442. https://doi.org/10.1016/0305-0483(95)00017-I

Tsimonis, G., \& Dimitriadis, S. (2014). Brand strategies in social media. Marketing Intelligence \& Planning, 32(3), 328-344. https://doi.org/10.1108/MIP-04-2013-0056

Uzunoğlu, E., Türkel, S., \& Akyar, B. Y. (2017). Engaging consumers through corporate social responsibility messages on social media: An experimental study. Public Relations Review, 43(5), 989-997. https://doi.org/10.1016/j.pubrev.2017.03.013

Waddock, S. A., \& Graves, S. B. (1997). The corporate social performance-financial performance link. Strategic Management Journal, 18(4), 303-319.

https://doi.org/10.1002/(SICI)1097-0266(199704)18:4<303::AID-SMJ869>3.0.CO;2-G

Wamba, S. F., \& Carter, L. (2014). Social media tools adoption and use by SMEs: An empirical study. Journal of Organizational and End User Computing, 26(2), 1-16. https://doi.org/10.4018/joeuc.2014040101

We Are Social. (2020). Digital 2020. October Stathot Report. https://wearesocial.com/blog/2020/10/ social-media-users-pass-the-4-billion-mark-as-global-adoption-soars

Welch, E. W., Hinnant, C. C., \& Moon, M. J. (2005). Linking citizen satisfaction with e-government and trust in government. Journal of Public Administration Research and Theory, 15(3), 371-391. https://doi.org/10.1093/jopart/mui021

Wigley, S. (2008). Gauging consumers' responses to CSR activities: Does increased awareness make cents? Public Relations Review, 34(3), 306-308. https://doi.org/10.1016/j.pubrev.2008.03.034

Wilberding, K., \& Wells, G. (2019). Facebook's timeline: 15 Years in. The Wall Street Journal, February 6. https://www.wsj.com/articles/facebooks-timeline-15-years-in-11549276201

Wong, A., Ho, S., Olusanya, O., Antonini, M. V., \& Lyness, D. (2020). The use of social media and online communications in times of pandemic COVID-19. Journal of the Intensive Care Society, 1-6. https://doi.org/10.1177/1751143720966280

Wu, M. W., \& Shen, C. H. (2013). Corporate social responsibility in the banking industry: Motives and financial performance. Journal of Banking \& Finance, 37(9), 3529-3547. https://doi.org/10.1016/j.jbankfin.2013.04.023

Yusof, J. M., Manan, H. A., Karim, N. A., \& Kassim, N. A. M (2015). Customer's loyalty effects of CSR initiatives. Procedia - Social and Behavioral Sciences, 170, 109-119.

https://doi.org/10.1016/j.sbspro.2015.01.020 